\title{
Life cycle (well-to-wheel) energy and environmental assessment of natural gas as transportation fuel in Pakistan
}

Article

Accepted Version

Creative Commons: Attribution-Noncommercial-No Derivative Works 4.0

Khan, M. I., Shahrestani, M., Hayat, T., Shakoor, A. and Vahdati, M. (2019) Life cycle (well-to-wheel) energy and environmental assessment of natural gas as transportation fuel in Pakistan. Applied Energy, 242. pp. 1738-1752. ISSN 0306-2619 doi: https://doi.org/10.1016/j.apenergy.2019.03.196 Available at https://centaur.reading.ac.uk/83261/

It is advisable to refer to the publisher's version if you intend to cite from the work. See Guidance on citing.

Published version at: https://www.sciencedirect.com/science/article/pii//S0306261919306129

To link to this article DOI: http://dx.doi.org/10.1016/j.apenergy.2019.03.196

Publisher: Elsevier

All outputs in CentAUR are protected by Intellectual Property Rights law, including copyright law. Copyright and IPR is retained by the creators or other copyright holders. Terms and conditions for use of this material are defined in the End User Agreement.

www.reading.ac.uk/centaur 
Central Archive at the University of Reading

Reading's research outputs online 


\title{
Life Cycle (Well-to-Wheel) Energy and Environmental Assessment of Natural Gas as Transportation Fuel in Pakistan
}

\author{
Muhammad Imran Khan ${ }^{1,4, *}$, Mehdi Shahrestani ${ }^{1}$, Tasawar Hayat ${ }^{2,3}$, Abdul Shakoor ${ }^{4}$, Maria Vahdati ${ }^{1}$ \\ ${ }^{1}$ School of the Built Environment, University of Reading, RG6 6AW, Reading, UK \\ ${ }^{2}$ Nonlinear Analysis and Applied Mathematics (NAAM) Research Group, Department of Mathematics, Faculty of Science, King Abdulaziz \\ University, Jeddah, Saudi Arabia \\ ${ }^{3}$ Department of Mathematics, Quaid-i-Azam University, Islamabad 44000, Pakistan \\ ${ }^{4}$ Department of Mechanical Engineering, University of Engineering \& Technology, Peshawar, Pakistan \\ *Corresponding author: imran.hwu@gmail.com
}

\begin{abstract}
Consumers and organizations worldwide are searching for low-carbon alternatives to conventional gasoline and diesel vehicles to reduce greenhouse gas (GHG) emissions and their impact on the environment. Natural gas as an alternative transportation fuel has made significant inroads in the light and heavy duty vehicles market over the last fifteen years. In a sustainable development view, both vehicle emissions and energy supply chain analysis from well-to-wheel must be addressed. The aim of this research is to provide a Well-to-Wheel (WtW) assessment of energy consumptions and GHG emissions for 25 combinations of automotive fuel and matching powertrain systems, with a special focus on the natural gas pathways. Although several well-towheel studies available in literature are comprehensive in relation to developed countries' conditions, it is problematic to apply the results to developing countries fuel markets, since the local fuel conditions and respective vehicle powertrain technologies are considerably different. This study deal with a comparative well-to-wheel analysis of natural gas, diesel and gasoline fuels looking at the Pakistanis situation but the models and approaches for this study can be applied to other countries having similar characteristics, as long as all the assumptions are well defined and modified to find a substitute automotive energy source and establish an energy policy in a specific region. The well-to-tank step was made using the GREET model, developed by the U.S. Argonne National Laboratory while tank-to-wheel analysis was performed using AVL Cruise, a commercially-available backward vehicle simulator. Later both stages were integrated in a well-to-wheel stage where relevant indexes were proposed and discussed. The results indicate that natural gas vehicles are 5-17\% and $23-36 \%$ less fuel efficient, depending on the engine technology employed as compared to gasoline and diesel powertrain, respectively. Natural gas appears as an environmental efficient pathway regarding GHG emissions, especially compared to gasoline. In addition, using 20-year GWPs instead of 100-year GWPs increases WtW GHG emissions by $19-26 \%$ for natural gas pathways.
\end{abstract}

Key Words: Well-to-wheel; GHG emissions; natural gas vehicles; automotive fuels.

\section{Introduction}

The Paris Agreement - the first-ever universal, legally binding global climate deal - was adopted by 195 countries at the Paris Climate Conference (COP21) in December 2015. The Paris Agreement requires all Parties to put forward their best efforts through "nationally determined contributions" (NDCs) to greatly reduce greenhouse gas (GHG) emissions. Being the world's $6^{\text {th }}$ most populated nation, its energy requirement establishes Pakistan as a major contributor of 
GHG emissions; therefore, the reduction of the GHG emissions in Pakistan has attracted substantial local attention. The energy consumption of the road transportation sector accounts for $33 \%$ of the total energy consumption in Pakistan [1] and is responsible for a significant share (around 25\%) of GHG emissions nationwide [2]. Therefore the reduction of GHG emissions in the transportation sector is a top priority of the government [3].

Emissions and energy consumption are often measured at the point of use. This does not, however, account for the overall emissions and energy consumption. To evaluate the impact of fuels and energy carriers the whole supply chain has to be considered [4]. To evaluate and assess the energy consumption, emissions, and economic effects of automotive fuels and vehicle technologies, a holistic or comprehensive approach has to be considered. The approach, often referred to as life cycle approach, or life cycle assessment (LCA), which must include all the steps required to produce a fuel, to manufacture a vehicle, and to operate and maintain the vehicle throughout its lifetime including disposal and recycling at the conclusion of its life cycle. A lifecycle analysis of energy consumed and emissions generated is especially important for technologies that employ fuels with different primary energy sources and fuel production processes. A typical life cycle of a vehicle technology is shown in Fig. 1. The life cycle can be classified into two major categories: the fuel cycle and the vehicle cycle. The fuel lifecycle analysis, also known as well-to-wheel analysis is vital for selecting vehicle fuels and technologies for the future.

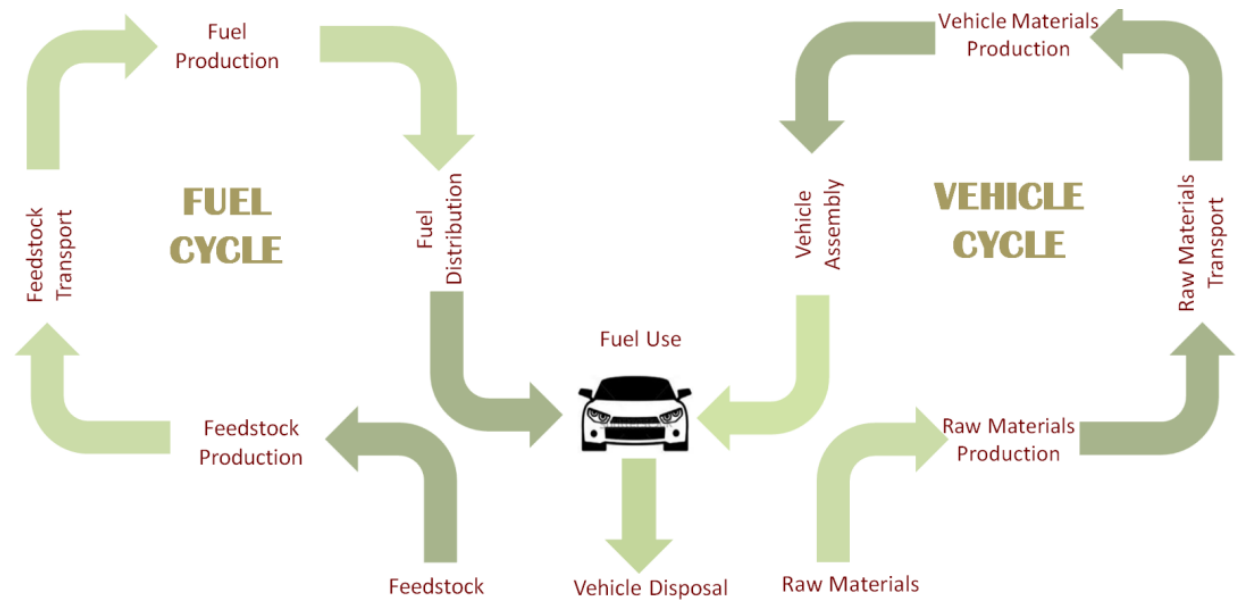

Fig.1. Typical life cycle of a vehicle technology

The well-to-wheel analysis indicates the study of the energy use and GHG emissions in the production of the fuel and its use in the vehicle or engine, hereinafter called WtW analysis. Compared to Life Cycle Assessment (LCA) a WtW analysis can have the same system boundaries but does not consider energy or emissions involved in the construction of the facilities, the vehicles, consumption of other materials, water, and end of life disposal [5]. The whole WtW cycle is comprised of two independent stages, as shown in Fig 2. These include (i) a Well-to-Tank (WtT) stage, which includes the recovery or production of the feedstock for the fuel, transportation and storage of the energy source through conversion of the feedstock to the fuel and the subsequent transportation, storage, and distribution of the fuel to the vehicle tank, 
and (ii) a Tank-to-Wheel (TtW) stage, which refers to the vehicle in utilizing the fuel for traveling purposes throughout its lifetime.

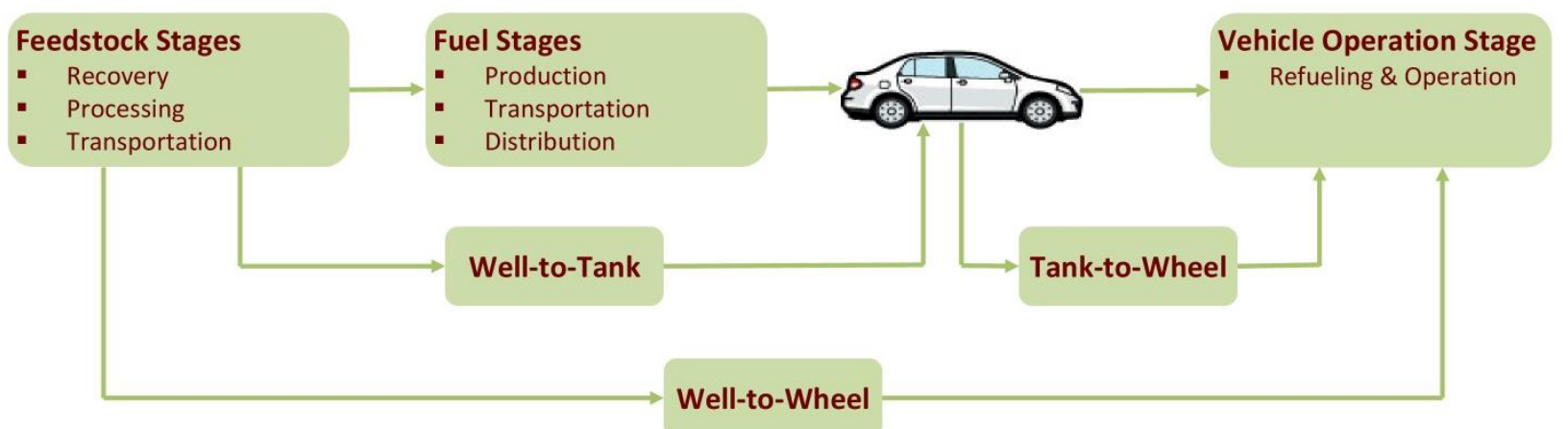

Fig. 2. System Boundary of Well-to-Wheel Analysis of the Case Study Fuels

The rest of this paper is structured as follows: Section 2 reviews the existing literature. Section 3 presents the objectives of the present study. Section 4 defines the key assumptions and parameters used in well-to-wheel analysis including functional unit, GHG coefficients, fuel pathways, and methane slip/leakage and vehicle technologies. Section 5 describes the research methodology and data. The results and discussion are reported in Section 6. A comparative analysis of this study with previous studies is presented in Section 7. Section 8 concludes the outcomes of the study.

\section{Review of the state-of-the-art}

Many variations of WtW studies [6-18] have been proposed in the literature to capture different aspects of the fuel life-cycle of transportation fuels for various propulsion in different regions of the world. However WtW studies on CNG vehicles haven't got much academic interest and only few analyses have been conducted targeting the CNG fuel, with often varied and even contrasting results. In this section we have presented a brief review of those WtW studies pertaining to $\mathrm{CNG}$.

The first comprehensive WtW analysis study [19] was performed by General Motors and Argonne National Laboratory. The analysis based on the U.S. market which includes a set of 75 different fuel pathways and 15 vehicle powertrains, aimed at informing public and private decision 65 makers on the impact of diverse fuel/vehicle systems. GREET was used for the WtT tank stage, while proprietary 66 GM models were used to compute TtW energy consumption and emissions. The results revealed that on WtW energy basis CNG consume $4 \%$ and $25 \%$ more energy than gasoline and diesel fuel vehicle respectively. Similarly for GHG emission the study estimated that $\mathrm{CNG}$ produce $8 \%$ less GHG emission than gasoline while $6 \%$ more than conventional diesel fuel. Another WtW study in US setting was conducted by Waller et al. 2014 [20]. This study compare the current and theoretical maximum well-to-wheels energy efficiencies of passenger vehicles using natural gas in three different ways: via direct use in a CNG vehicle, for production of hydrogen used in a fuel cell vehicle, and to generate electricity 
for a battery electric vehicle. The study reveals the best current and theoretical maximum WTW energy efficiencies corresponding to $31 \% / 63 \%, 25 \% / 87 \%$ and $44 \% / 84 \%$ for CNG, FCEV, and BEV pathways respectively. In the European context, the Joint Research Center (JRC) has recently published WtW study based on 2010 vehicle-fuel specific data with predictions for the period beyond the year 2020 [21]. This study considered a C-segment 5-seater sedan as a reference vehicle and simulated vehicles on NEDC (New European Drive Cycle) for TtW evaluations. For TtW analysis, a wide range of fuel-powertrain combinations were considered. The major fuels considered were: gasoline, diesel, LPG, CNG, hydrogen and bio-diesel. For CNG fuel two pathways were considered i.e. (i) imported natural gas via $4000 \mathrm{~km}$ pipeline and (ii) natural gas from imported LNG. The results show that on WTW basis CNG is less energy efficient than gasoline and diesel fuel. Similarly for GHG the study shows that CNG produce less emission than gasoline and more emission than diesel fuel. Another study by Torchio et al. 2014 [22] described a WtW analysis in the European context introducing a new global index by assigning costs to energy, emissions and other factors. This study concludes that usage of natural gas-based fuels and hybridization as promising options compared to conventional gasoline and diesel fuel vehicles. Similarly a WtW analysis by Yazdanie et al. 2014 [23] concerned the operation of conventional and alternative passenger vehicles in Switzerland. This analysis showed that HEVs using alternate fuels particularly biogas and CNG resulted in remarkable reductions in WTW energy and GHG emissions over a conventional gasoline-powered IC engine vehicle. In Australia, as part of the Sustainable Transport Energy Program (STEP), Ally et al. 2007 [24] did an LCA comparison of bus fleets powered by diesel, CNG and hydrogen fuel cell respectively. They showed that CNG required more energy per distance traveled and resulted in slightly higher GHG emissions compared to diesel driven vehicles. However, vehicles driven by CNG showed lower emissions related to smog, acidification, and soil/water contamination (NOx, $\mathrm{CO}, \mathrm{SO} 2$, and non-methane volatile organic compounds) for Western Australia. In Canadian setting, Rose et al. 2013 [25] carried out a comparative LCA with GHGenius (LCA model developed for Canadian Transport system) on refuse collection vehicles powered by diesel and $\mathrm{CNG}$ and found that a $24 \%$ reduction of GHG emissions was achieved by switching from diesel to CNG. In US context, Tong et al. 2015 [26, 27] WtW GHG emissions of light-duty and heavyduty vehicles fueled by natural gas were examined and compared to their gasoline and diesel counterparts, and vehicle fuel efficiency and methane leakage rate of the natural gas supply chain were found to be major drivers to the relative GHG emission performances of NGVs. In China, Karman et al. [28] presented the results from an assessment of WtW GHG emissions from buses fuelled with diesel and CNG in the city of Beijing. The model employed was the 'China version' of 'GHGenius', created by using specific data and estimates wherever China specific information was available to replace its default data for North America. It was found that GHG emissions 'per vehicle-kilometre driven' for CNG were slightly lower than those for diesel. In another study, Ou et al. 2010 [29] employed Tsinghua-CA3EM model to compare the WtW performance of alternative fuel buses with conventional buses specific to China. They showed that CNG buses consumes $14 \%$ less energy and produce $28 \%$ less GHGs than a counterpart diesel vehicle. Likewise Patil et al. [30] conducted a country specific WtW analysis of automotive fuels for India. Specifically, 28 vehicle/fuel configurations of a subcompact passenger car were selected for a detailed analysis in the Indian context. The results revealed that on $\mathrm{WtW}$ basis $\mathrm{CNG}$ produce $\sim 26 \%$ less GHG emission than gasoline while $\sim 7 \%$ more than conventional diesel fuel. Curran et al. 2014 [31] used the GREET model to analyze the WtW energy use and GHG 
emissions from natural gas pathways. They specifically compared CNG vehicles and electric vehicles charged with natural gas-based electricity and found that the latter is better.

It is clear from the above literature that most of the WtW studies mostly focus on developed countries. The nature of choices and assumptions made in these WtW studies are likely to be subjective. Therefore results of WtW studies focused on developed economies like USA, Europe may not be appropriate for developing countries applications. It is problematic to apply the results of LCA studies conducted for developed countries to developing countries fuel markets like Pakistan, since the local conditions and respective vehicle powertrain technologies are considerably different. To the best of our knowledge, no comprehensive WtW assessment of transportation, especially for fuels with commercial availability, has been fully investigated in the developing countries. WtW modeling for different fuel pathways in the developing countries using a unified but comprehensive and systematic computing platform is problematic because: (1) relatively limited data are available, (2) cooperation between related research institutes is weak, and (3) funding for long-term research has been insufficient. Moreover most of the WtW studies available in the literature used the GREET model to estimate the emission reduction potentials and the fuel efficiency of natural gas pathways compared to petroleum fuels. However these studies failed to include a comprehensive set of pathways and used outdated data with regard to natural gas upstream emissions and global warming potential (GWP). In addition they largely ignored uncertainty and variability, especially those related to fugitive methane emissions from natural gas systems. The present study addresses these limitations and provides an independent emission inventory in addition to the GREET model.

Therefore the aim of this study is to construct the first comprehensive WtW GHG database of petroleum-based automotive fuels commercially available in Pakistan that will be essential to meet the rising stringent emission standards and to evaluate the best fuel option for Pakistan. The study presents a detailed $\mathrm{WtW}$ analysis to compare vehicles fueled with CNG, gasoline and diesel. The comparison is based on two indicators: i) primary energy consumption, and ii) GHG emissions. Instead of simply listing the comparisons, this paper discusses the reasons that cause the changes in the efficiencies and emissions that are brought about by automotive fuels.

This study is designed with the view of helping policy makers to answer the following questions:

- Based on the evaluation of the WtW cycles of automotive fuels specific to Pakistan, which fuel option among the selected fuel/power types would have the least harmful environmental impact overall?

- Which life cycle phase contributes the most to each of the different possible environmental impacts?

- Which uncertainties in life cycle analyses could most drastically affect the environmental performance of CNG vehicles?

This study distinguishes itself from previous efforts in the following ways:

- This is the first study to consider a detailed WtW analysis of CNG fuel with three different pathways (i.e. domestic natural gas, interstate gas pipeline and LNG) in developing and energy importing countries like Pakistan. Moreover, this study is the first initiative in the developing countries to consider $\mathrm{TtW}$ analysis for a $\mathrm{C}$-segment passenger car equipped with gasoline (PISI and DISI), diesel, dedicated CNG (PISI and DISI) and bi-fuel CNG engine (PISI and DISI) technology. This combined with the variety of fuel pathways considered 
makes this, to the best of our knowledge, the most comprehensive WtW analysis of fossil fuels available to date

- Other than being the first comprehensive country specific WtW study for Pakistan, the novelty of this work lies in the use of a consistent framework across multiple powertrain types with the same operating conditions to assess energy consumption and operating emissions.

- The study integrates the microscopic base emission model AVL Cruise coupled with the macroscopic base emission model GREET for WtW analysis under specific regional conditions.

- This study reports a comparison of WtW GHG emissions for CNG, diesel and gasoline vehicles using global warming potential(GWP) with both 100 -years and 20 -years based on the latest $5^{\text {th }}$ assessment report released by Intergovernmental Panel on Climate Change (IPCC 2013) [32]. All else being equal, the choice of time horizon for GWP greatly changes the equivalent $\mathrm{CO}_{2}$ emissions of methane, which has a much higher GWP over 20 years than over 100 years.

\section{Methodology and data}

As mentioned above the WtT cycle consist of two stages i.e (i) WtT stage, and (ii) TtW stage. The WtT stage of study has been covered in part-1 [33] of this two-part study. In this paper the Well-to-Tank (WtT) results observed in part-1[33] are combined with the TtW (Tank-to-Wheel) results reported in this present paper to provide the comprehensive WtW(Well-to-Wheel) results for the operation of conventional and CNG passenger vehicle drivetrains specific to Pakistan.

Tank-to-Wheel phase of the Well-to-Wheel cycle considers the energy use and emissions associated with the operation of a vehicle. Different factors affect emissions from motor vehicles, including travel, driver, facility, vehicle, fuel and overall environmental characteristics. Travel-related factors include vehicle engine operating modes or temperatures (cold and hot starts, hot stabilized periods), speeds, accelerations and decelerations. Significant impacts on emission levels are also influenced by those driver behaviors causing speed variations in response to specific traffic conditions, vehicle and fuel types, thus imposing heavy loads on the engine. Facility-related factors, which include infrastructure engineering features and traffic signals, are supposed to encourage low-emitting speeds or operating modes. Emission rates further depend on vehicle-related factors such as age, mileage, maintenance conditions, weight, size, engine power, fuel delivery system, emission control system. Furthermore, environmental factors (air temperature, altitude, humidity) play an important role in affecting the emissions.

The review of existing methods provides evidence that generally a computer based emission model is used to incorporate the effects of the above mentioned factors in the measurement of energy consumption and emissions during the operation of a vehicle. The literature encompasses the two general approaches (i.e. Macroscopic models and Microscopic models) used to estimate vehicle emissions and fuel consumption. The macroscopic modeling approach uses average aggregate network parameters to estimate network-wide emission rates according to high-level relationships among density, flow, and speed of traffic flows on urban road networks [34]. These models develop emission and fuel consumption factors based on macroscopic activity, like transport productivity or Vehicle Travel Kilometers (VTK). For macroscopic emissions models, 
only a macroscopic emission estimation approach can be applied, since detailed individual vehicle data is not available in these models. This type of models is generally used in case of modeling emissions of transportation systems in a large scale strategic level, like national road network or regional scale. The popular example of this type includes MOBILE, EMFAC, COPERT, IVE Model [35].

The microscopic models describe individual vehicle movements through the traffic simulation model. In these models, each vehicle moves through the traffic network with updated character which is determined by speed, acceleration, time, and individual driver behavior. The driver behavior is determined by a set of models such as car following, lane changing, acceleration noise and etc. Its application envelope covers conventional vehicle powertrains through to highly-advanced hybrid systems and pure electric vehicles. Examples of this type include MOVES, CMEM, PHEM, ADVISOR, Autonomie, and AVL CRUISE.

To estimate the comparative tank-to-wheel energy use and emissions associated with the operations of CNG, gasoline and diesel vehicle specific to Pakistan, this study used AVL Cruise, a commercially-available backward vehicle simulator for GHG emission and energy use [36]. AVL CRUISE is an example of a micro-scale instantaneous emission model base tool which enables the user to design a specific passenger vehicle and simulate fuel consumption and emissions under different operating conditions. It is considered to be one of the industry's most powerful, robust and adaptable software for vehicle system and driveline analysis with advanced simulation and optimization features [37]. It helps efficiently developing the right decisions leading to competitive vehicles with respect to fuel efficiency, emissions, performance and drive ability [38]. In AVL Cruise the architectures of any kind of drivetrain can be modeled by using the available component blocks e.g. IC engines, clutches, transmission elements, controls, shafts, wheels/tires, electrical components, brakes, auxiliaries, curb weight and others. So it can simulate any passenger vehicle commercially available in the market. The engine's performance, fuel consumption, emissions etc. are all based on stationary measured curves and maps. This means it does not really know what type of engine you are simulating and what fuel you want to use as energy source. What it needs is a full load characteristic of the engine, a motoring curve of the engine and then the fuel consumption map, where you input the fuel consumption either as volume flow or mass flow depending on Engine speed and Engine torque or Power. It also facilitates the user to input the emission maps for $\mathrm{NOx}, \mathrm{CO}, \mathrm{HC}$ and Soot. Due to these structured interfaces and advanced data management concept, AVL Cruise has established itself as a data communication and system integration tool for different teams within world-leader OEM's and their suppliers [39]. CNG vehicles are not included in AVL Cruise. To include this technology, an adhoc CNG vehicle model has been implemented in AVL Cruise using experimental data provided by a Pakistani OEM automaker. In order to simulate a vehicle, a template model structure (Fig. 3) has been developed. It consists of components that actual vehicles have (such as IC engine, gearbox, wheels, brakes, etc.), functions that control the operation of each component and the necessary connections between them. Each component is described by a number of parameters and is configurable in such an extent that it can reproduce most of the representative vehicles (e.g. diesel, gasoline, CNG) selected for this study. The connections can be either mechanical, allowing mechanical power flow (for example ICE $\rightarrow$ clutch $\rightarrow$ gearbox), electrical (battery $\rightarrow$ starter), or informational (control functions). All 
vehicle models assessed in this study are simulated over New European Driving Cycle (NEDC) for predicting fuel economy and carbon dioxide emissions.

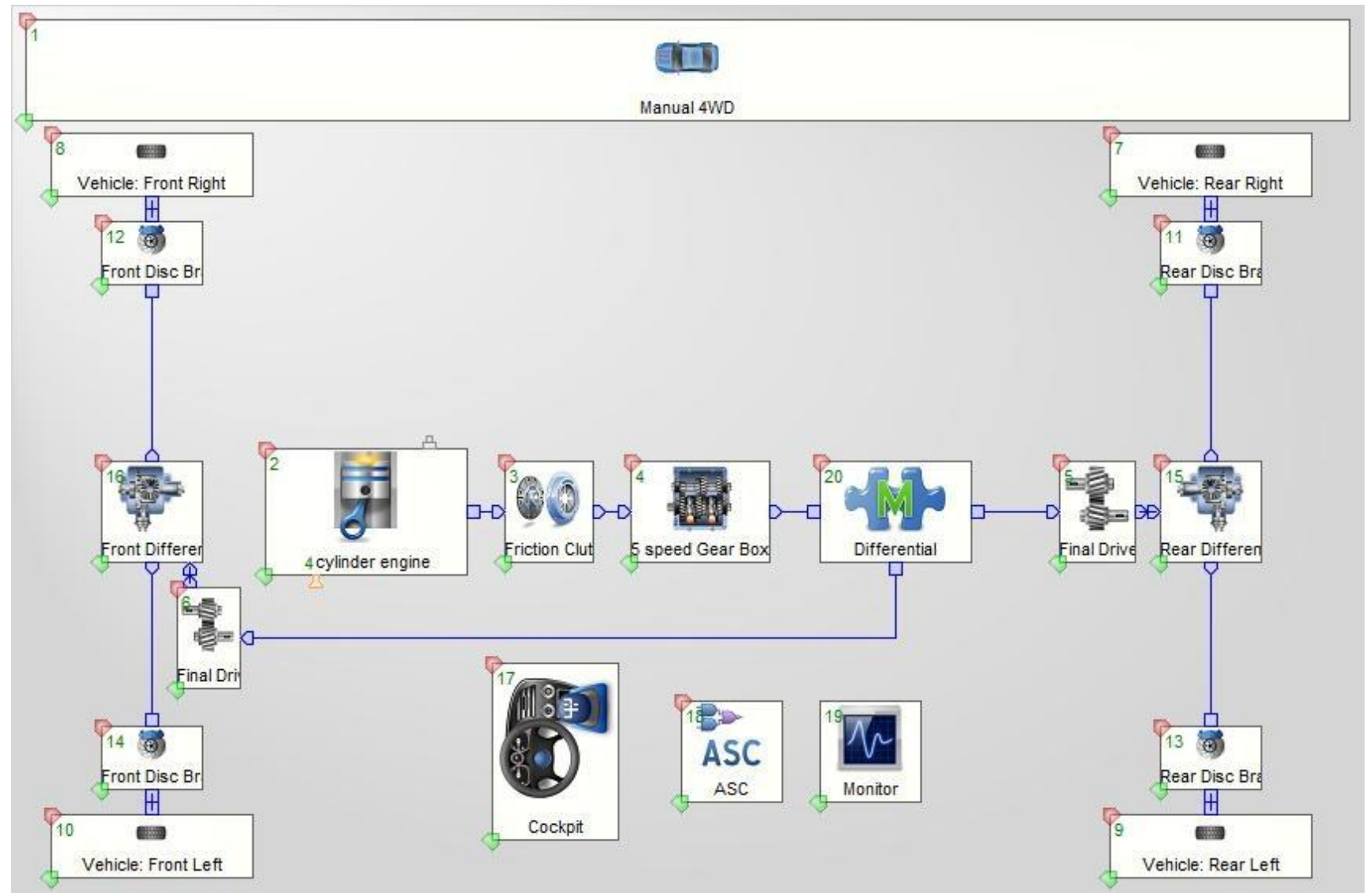

Fig. 3. Template topology for conventional vehicles in the AVL CRUISE environment

\section{Key Assumptions and Parameters:}

Following are key parameters and assumptions used in this study:

\subsection{Function Unit}

This study used the following important function units:

- WtT stage energy consumption is calculated on a megajoule per megajoule (MJ/MJ) basis.

- TtW and WtW stage energy consumption is calculated on a megajoule per-kilometer $(\mathrm{g} / \mathrm{km})$ basis.

- WtT stage emissions are calculated on a gram per megajoule $(\mathrm{g} / \mathrm{MJ})$ basis.

- TtW stage emissions are calculated on a gram per-kilometer $(\mathrm{g} / \mathrm{km})$ basis.

- WtT results are combined with TtW results and overall WtW energy consumption and GHG emission are calculated on $\mathrm{g} / \mathrm{MJ}$ and $\mathrm{g} / \mathrm{km}$, respectively. The different functional units associated with WtT and TtW stages, are linked through formulas: 
WtT energy in $\left[\frac{M J}{k m}\right]=W t T$ energy in $\left[\frac{M J}{M J}\right] x$ TtW energy in $\left[\frac{M J}{k m}\right]$

Similarly

$$
\text { WtT GHG in }\left[\frac{g \mathrm{CO}_{2} e q}{\mathrm{~km}}\right]=W t T \text { GHG in }\left[\frac{g \mathrm{CO}_{2} e q}{M J}\right] \times \mathrm{TtW} G H G \text { in }\left[\frac{g \mathrm{CO}_{2} e q}{\mathrm{~km}}\right]
$$

\subsection{GHG coefficients}

The $\mathrm{CO}_{2}$ equivalence is applied to the non- $\mathrm{CO}_{2}$ greenhouse gases according to the 100 year and 20 year conversion coefficients recommended by the latest 5 th assessment report of the Intergovernmental Panel for Climate Change (IPCC 2013) [32] tabulated below (Table 1).

Table 1.IPCC GWP values of greenhouse gases

\begin{tabular}{lll}
\hline \multirow{2}{*}{ GHG } & \multicolumn{2}{c}{ GWP value } \\
\cline { 2 - 3 } & $\begin{array}{l}\text { 100 year time } \\
\text { horizon }\end{array}$ & $\begin{array}{l}20 \text { year time } \\
\text { horizon }\end{array}$ \\
\hline $\mathrm{CO}_{2}$ & 1 & 1 \\
$\mathrm{CH}_{4}$ & 28 & 84 \\
$\mathrm{~N}_{2} \mathrm{O}$ & 265 & 265 \\
\hline
\end{tabular}

\subsection{Vehicle Emission control technologies}

In developed countries today, the vehicles' emissions compliance is accomplished through engine management, along with a suite of advanced catalyst technologies, including: three-way catalyst (TWC), diesel particulate filter (DPF), diesel oxidation catalyst (DOC), selective catalytic reduction (SCR), and lean NOx traps (LNT). However in the developing countries like Pakistan, these vehicle emission after-treatment technologies (ATT) are still very rare. Therefore in this study all the vehicle technologies are modeled without ATT.

\subsection{Pakistan's Fuel Mix}

Before discussing the WTT fuel pathways for various transportation fuels in Pakistan, the statistical highlights of road transportation fuels are presented in Appendix A.

\subsection{Fuel pathways}

The study considers three type of fuels (CNG, gasoline \& diesel) extracted from 10 different fuel pathways. Table 2 illustrates the fuel pathways considered in this study. 
Table 2. Fuel Pathways considered in this study

\begin{tabular}{|c|c|c|c|c|}
\hline \multirow{2}{*}{ Fuel Type } & \multirow{2}{*}{ Symbol } & LHV & $\begin{array}{l}\text { RON / } \\
\text { CN }\end{array}$ & \multirow{2}{*}{$\begin{array}{l}\mathrm{CO}_{2} \text { Emission } \\
\text { factor } \\
\mathrm{g} / \mathrm{MJ}\end{array}$} \\
\hline & & $\mathrm{MJ} / \mathrm{kg}$ & & \\
\hline Gasoline (produced at local refineries from indigenous crude oil sources) & F1 & 43.2 & 93 & 73.4 \\
\hline Gasoline (produced at local refineries from imported crude oil sources) & F2 & & & \\
\hline Gasoline (imported from Middle east) & F3 & & & \\
\hline CNG (produced from indigenous gas sources) & $\mathrm{F} 4$ & 45.1 & & 56.2 \\
\hline CNG (produced from imported gas through IP Pipeline) & F5 & & & \\
\hline CNG (produced from imported gas through TAPI Pipeline) & F6 & & & \\
\hline CNG (produced from imported LNG) & F7 & & & \\
\hline Diesel (produced at local refineries from indigenous crude oil sources) & F8 & 43.1 & 51 & 73.2 \\
\hline Diesel (produced at local refineries from imported crude oil sources) & F9 & & & \\
\hline Diesel (imported from Middle east) & F10 & & & \\
\hline
\end{tabular}

\subsection{Reference Vehicle and vehicle technologies}

All simulations are based on a generic or "virtual" reference vehicle, representing a common Pakistani C-segment 5-seater sedan, comparable to e.g. a Toyota GLI or Honda City or others in that class. This reference vehicle is used as a tool for comparing the various fuels and associated technologies covered in this study. Base vehicle characteristics and vehicle technologies considered in this study are given in Table 3. Combining the fuel pathways shown in Table 2 with the vehicle technologies listed in Table 3 , results in 25 powertrain configuration (Table 4). 
Table 3. Specification of reference vehicle technologies

\begin{tabular}{|c|c|c|c|c|c|c|c|c|}
\hline \multirow{3}{*}{ Description } & \multirow{3}{*}{ Unit } & \multicolumn{7}{|c|}{ Vehicle technology } \\
\hline & & \multicolumn{3}{|l|}{ PISI } & \multicolumn{3}{|l|}{ DISI } & \multirow{2}{*}{$\frac{\text { DICI }}{\text { Diesel }}$} \\
\hline & & Gasoline & $\begin{array}{l}\text { CNG } \\
\text { (Bi-fuel) }\end{array}$ & $\begin{array}{l}\mathrm{CNG} \\
\text { (dedicated) }\end{array}$ & Gasoline & $\begin{array}{l}\text { CNG } \\
\text { (Bi-fuel) }\end{array}$ & $\begin{array}{l}\mathrm{CNG} \\
\text { (dedicated) }\end{array}$ & \\
\hline Curb wright (including fuel) & $\mathrm{kg}$ & 1275 & 1275 & 1275 & 1275 & 1275 & 1275 & 1275 \\
\hline Weight class & $\mathrm{kg}$ & 1360 & 1360 & 1360 & 1360 & 1360 & 1360 & 1360 \\
\hline Width & $\mathrm{mm}$ & 1735 & 1735 & 1735 & 1735 & 1735 & 1735 & 1735 \\
\hline Height & $\mathrm{mm}$ & 1477 & 1477 & 1477 & 1477 & 1477 & 1477 & 1477 \\
\hline Drag coefficient & - & 0.29 & 0.29 & 0.29 & 0.29 & 0.29 & 0.29 & 0.29 \\
\hline Engine displacement & liter & 1.3 & 1.3 & 1.3 & 1.3 & 1.3 & 1.3 & 1.3 \\
\hline No. of cylinder & - & 4 & 4 & 4 & 4 & 4 & 4 & 4 \\
\hline Compression ratio & - & $10.5: 1$ & $11: 01$ & $12.7: 1$ & $10.5: 1$ & 11:01 & $12.7: 1$ & 17.6:1 \\
\hline Specific power & $\mathrm{kW} / \mathrm{lit}$ & 64 & & 57 & 64 & 58 & 64 & 55 \\
\hline Maximum power & $\begin{array}{l}\mathrm{kW} \\
@ \mathrm{rpm}\end{array}$ & $63 @ 6000$ & $86 @ 6000$ & $99 @ 5750$ & $90 @ 4300$ & 95@4800 & $99 @ 4300$ & $92 @ 4000$ \\
\hline Maximum torque & $\begin{array}{l}\mathrm{Nm} \\
@ \text { rpm }\end{array}$ & $121 @ 4400$ & $123 @ 4000$ & $170 @ 3500$ & $\begin{array}{l}200 @ 1750- \\
4000\end{array}$ & $140 @ 4200$ & $\begin{array}{l}220 @ 1750 \text { - } \\
4000\end{array}$ & $200 @ 1750$ \\
\hline BSFC @ 2000 rpm / 2bar & $\mathrm{g} / \mathrm{kWh}$ & 395 & 385 & 365 & 385 & 380 & 355 & 305 \\
\hline
\end{tabular}


Table 4. Combination of WtW fuel pathways and vehicle technologies combination

\begin{tabular}{|c|c|c|}
\hline WtT Fuel Pathway (F) & TtW Powertrain (P) & WtW Combination (FP) \\
\hline $\mathrm{F}_{1}$ & \multirow{3}{*}{ Gasoline PISI $\left(\mathrm{P}_{1}\right)$} & $\mathrm{F}_{1} \mathrm{P}_{1}$ \\
\hline $\mathrm{F}_{2}$ & & $\mathrm{~F}_{2} \mathrm{P}_{1}$ \\
\hline $\mathrm{F}_{3}$ & & $\mathrm{~F}_{3} \mathrm{P}_{3}$ \\
\hline $\mathrm{F}_{1}$ & \multirow{3}{*}{ Gasoline DISI $\left(\mathrm{P}_{2}\right)$} & $\mathrm{F}_{1} \mathrm{P}_{2}$ \\
\hline $\mathrm{F}_{2}$ & & $\mathrm{~F}_{2} \mathrm{P}_{2}$ \\
\hline $\mathrm{F}_{3}$ & & $\mathrm{~F}_{3} \mathrm{P}_{2}$ \\
\hline $\mathrm{F}_{4}$ & \multirow{4}{*}{ CNG Dedicated PISI $\left(\mathrm{P}_{3}\right)$} & $\mathrm{F}_{4} \mathrm{P}_{3}$ \\
\hline $\mathrm{F}_{5}$ & & $\mathrm{~F}_{5} \mathrm{P}_{3}$ \\
\hline $\mathrm{F}_{6}$ & & $\mathrm{~F}_{6} \mathrm{P}_{3}$ \\
\hline $\mathrm{F}_{7}$ & & $\mathrm{~F}_{7} \mathrm{P}_{3}$ \\
\hline $\mathrm{F}_{4}$ & \multirow{4}{*}{ CNG Bi-fuel PISI $\left(\mathrm{P}_{4}\right)$} & $\mathrm{F}_{4} \mathrm{P}_{4}$ \\
\hline $\mathrm{F}_{5}$ & & $\mathrm{~F}_{5} \mathrm{P}_{4}$ \\
\hline $\mathrm{F}_{6}$ & & $\mathrm{~F}_{6} \mathrm{P}_{4}$ \\
\hline $\mathrm{F}_{7}$ & & $\mathrm{~F}_{7} \mathrm{P}_{4}$ \\
\hline $\mathrm{F}_{4}$ & \multirow{4}{*}{ CNG Dedicated DISI $\left(\mathrm{P}_{5}\right)$} & $\mathrm{F}_{4} \mathrm{P}_{5}$ \\
\hline $\mathrm{F}_{5}$ & & $\mathrm{~F}_{5} \mathrm{P}_{5}$ \\
\hline $\mathrm{F}_{6}$ & & $\mathrm{~F}_{6} \mathrm{P}_{5}$ \\
\hline $\mathrm{F}_{7}$ & & $\mathrm{~F}_{7} \mathrm{P}_{5}$ \\
\hline $\mathrm{F}_{4}$ & \multirow{4}{*}{ CNG Bi-fuel DISI $\left(\mathrm{P}_{6}\right)$} & $\mathrm{F}_{4} \mathrm{P}_{6}$ \\
\hline $\mathrm{F}_{5}$ & & $\mathrm{~F}_{5} \mathrm{P}_{6}$ \\
\hline $\mathrm{F}_{6}$ & & $\mathrm{~F}_{6} \mathrm{P}_{6}$ \\
\hline $\mathrm{F}_{7}$ & & $\mathrm{~F}_{7} \mathrm{P}_{6}$ \\
\hline $\mathrm{F}_{8}$ & \multirow{3}{*}{ Diesel DISI $\left(\mathrm{P}_{7}\right)$} & $\mathrm{F}_{8} \mathrm{P}_{7}$ \\
\hline $\mathrm{F}_{9}$ & & $\mathrm{~F}_{9} \mathrm{P}_{7}$ \\
\hline $\mathrm{F}_{10}$ & & $\mathrm{~F}_{10} \mathrm{P}_{7}$ \\
\hline
\end{tabular}

\section{Results and Discussion}

In this study, a WtW analysis on 25 combinations of automotive fuel and matching powertrain systems available in Pakistan was conducted.

\subsection{WtT energy consumption and GHG emissions}

In first part [33] of this two-part study, a WtT analysis was conducted on 10 different combinations of transportation fuels in Pakistan (Table. 2). The resulting energy consumption and GHG emission obtained in part-1 [33] of this study are reproduced in Fig. 4 and Fig. 5, respectively. 


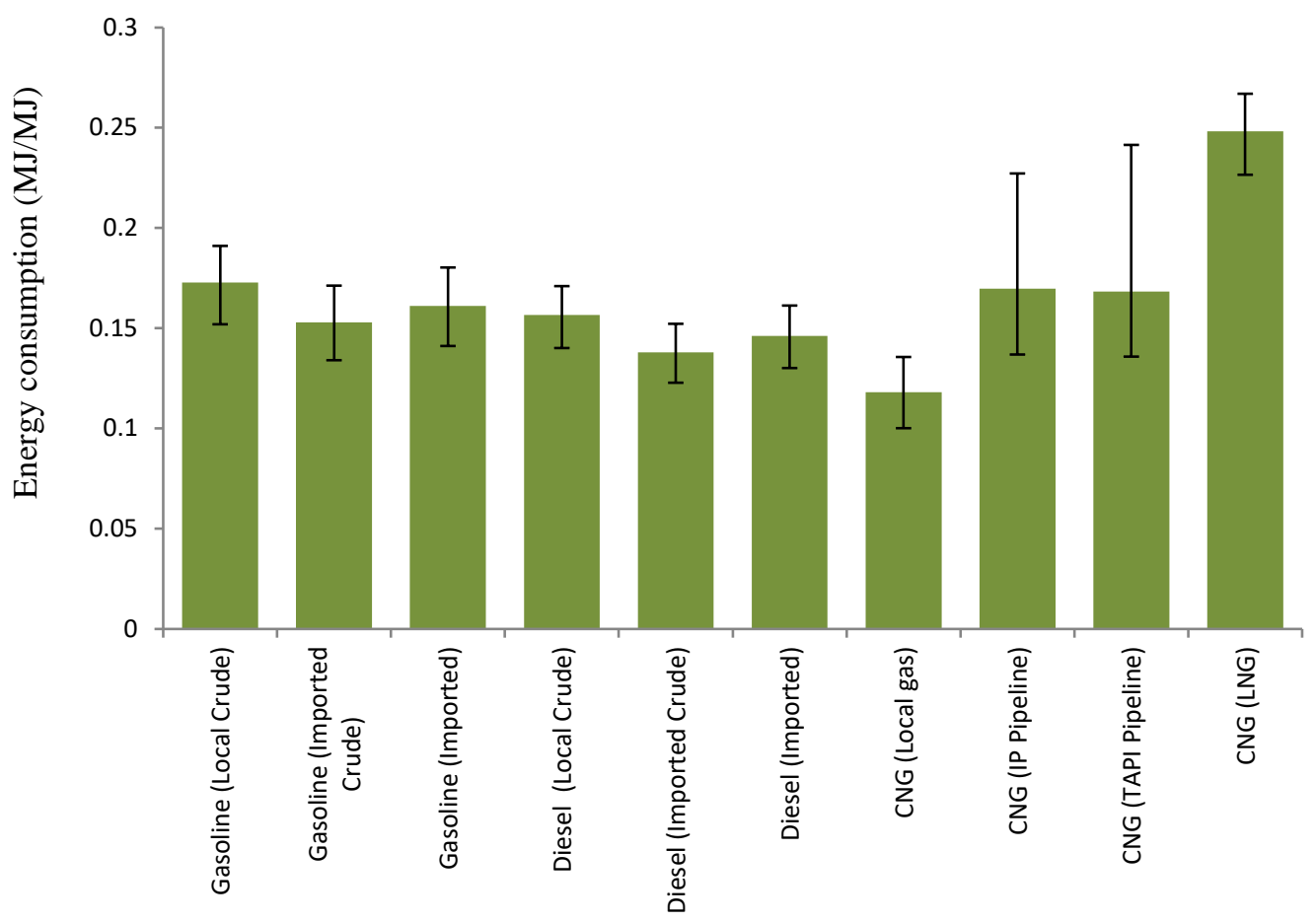

Fig. 4. WtT energy consumption for the selected pathways

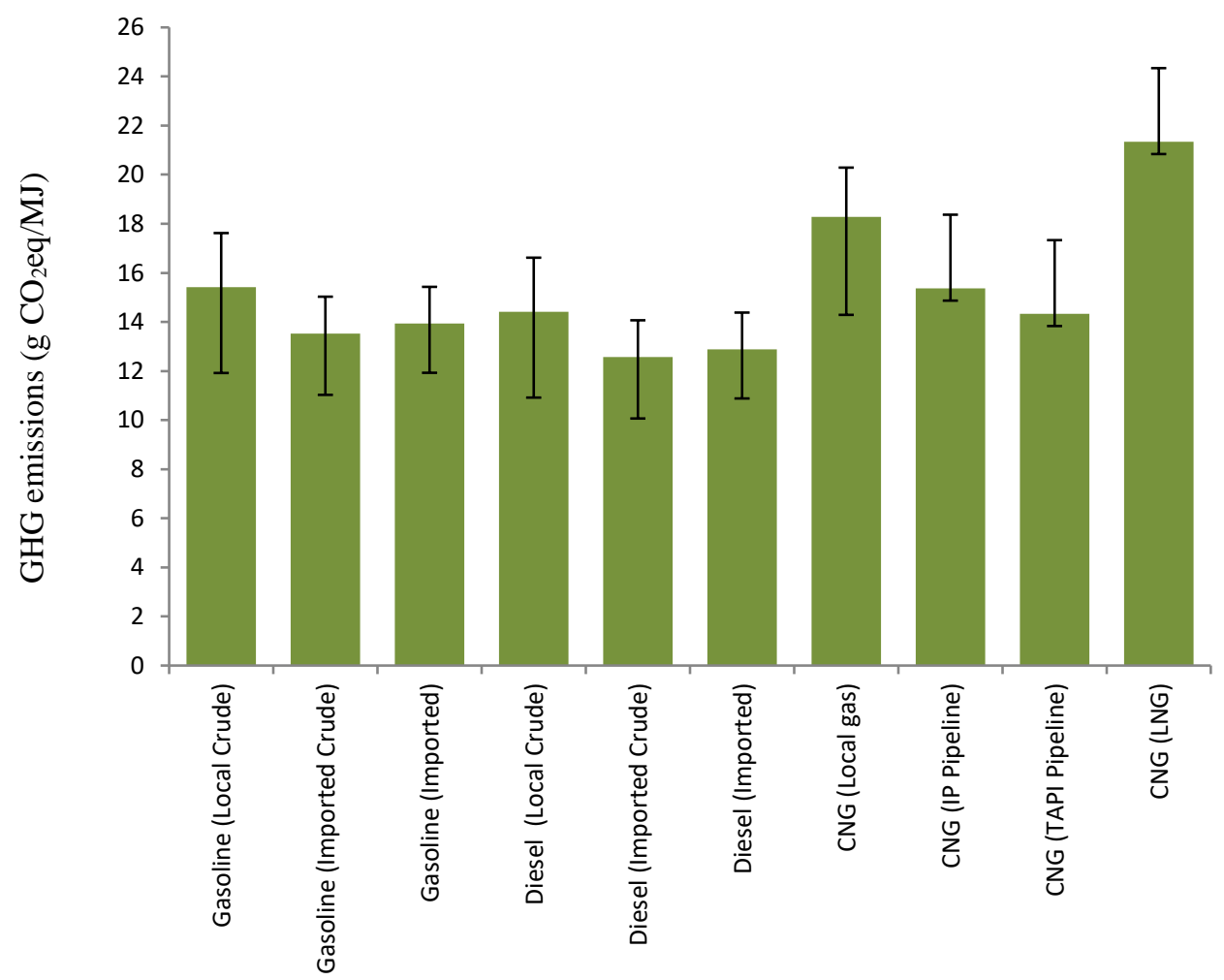

Fig. 5.WtT GHG emissions for the selected pathways 


\subsection{TtWAnalysis}

TtW analysis was conducted on seven different vehicle technologies highlighted in Table 4. The vehicle energy efficiency and GHG emissions results in $\mathrm{MJ} / \mathrm{km}$ and $\mathrm{g} \mathrm{CO}_{2} \mathrm{eq} / \mathrm{km}$, respectively are presented and discussed.

\subsection{TtW energy consumption}

The TtW energy efficiency for all powertrains are shown in Fig. 6.The energy efficiency for diesel-powered vehicle is expectedly better as compared to vehicles powered with gasoline, and CNG. This is due to the higher efficiency of the CI engine technology when compared to SI engine. It is observed that direct injection in SI engine can reduce TtW energy consumption by about $4.5-8 \%$. By injecting the fuel directly into each cylinder of the engine, better control of fuel's behavior can be achieved, improving the accuracy of air/fuel ratio during engine's dynamic performance, permitting use of higher compression ratios, and reducing the losses resulting from throttling the airflow in the standard port-injected SI engine [40]. The injected fuel, evaporates in the cylinder and causes to cool the intake charge. The cooling effect permits higher compression ratios and increasing of the volumetric efficiency and thus higher torque is obtained [40].The dedicated DISI natural gas vehicles show significantly improved fuel economy results as compared to bi-fuel CNG and gasoline vehicles using PISI \& DISI technology. The improvement in the TtW energy efficiency for DISI dedicated CNG vehicles can be attributed to the direct injection advantage over port injection and higher octane number of natural gas as compared to gasoline. Moreover dedicated CNG vehicles have SI engines that are operated only on natural gas. So compression ratio of these engine are optimized to utilize the advantage of high octane number (120) of natural gas which enhance engine thermal efficiency of about $10 \%$ above than that of gasoline engine [41]. Owing the above mentioned attributes, DISI engine technology provides significant improvements in fuel economy. However direct injection systems are more expensive as it requires costly and technically difficult modification to engine structure especially due to the need for extra hole for fuel injector. One other contributing factor toward the power loss in CNG engines is the stoichiometric air to fuel ratio (AFR) of natural gas. Natural gas has AFR of 17, compared to approximately 14.6 for diesel and gasoline. Since the mass of air inducted into the engine is limited, a higher AFR means less energy into the engine and lower peak power.

Bi-fuel PISI CNG vehicles show the worst TtW performance in terms of energy use, due to relatively low flame propagation of natural gas and loss in volumetric efficiency. Due to the low densities, gaseous fuels occupy 4-15\% of intake passage volume resulting in significant reduction of volumetric efficiency when compared to liquid fuels. Therefore lesser volumetric efficiency and flame propagation of natural gas reduces bi-fuel CNG engine power by $10 \%$ when compared to gasoline.

Although due to high octane value, the SI engine running on natural gas can be expected with relatively high thermal efficiency but retrofit $\mathrm{Bi}$-fuel $\mathrm{CNG}$ engines will not have the advantage of high octane value of natural gas as the compression ratio will be set to the level required for gasoline. It can be observed that in contrast to conventional PISI gasoline powertrain, bi-fuel CNG system will still be $6.3 \%$ less energy efficient even if it is equipped with a direct ignition 
system which shows that the engine's thermal efficiency has a significant impact on TtW energy efficiency.

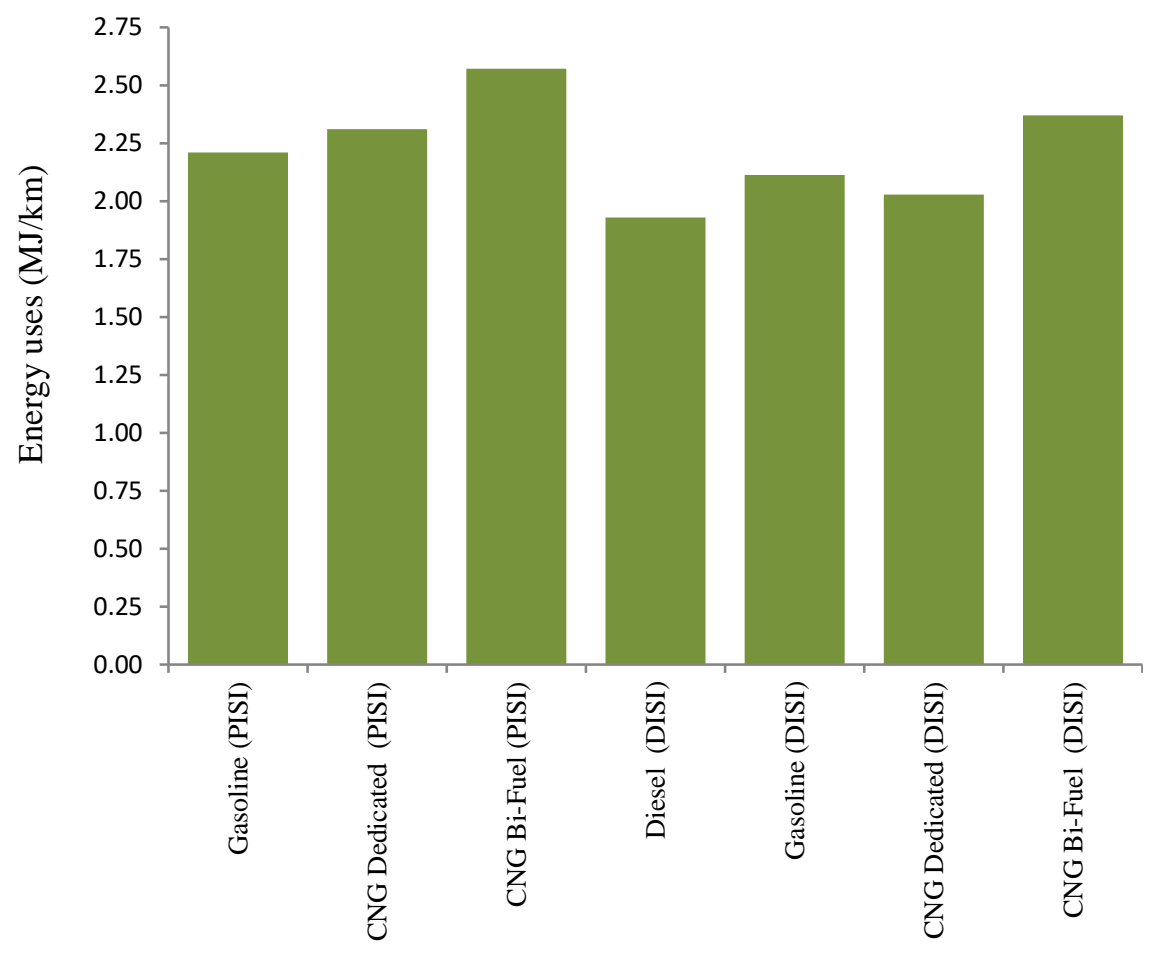

Fig. 6. TtWenergy uses for the selected powertrain technologies

\subsection{TtW GHG emission}

The GHG emissions results are presented in Fig. 7. Powertrain that run on natural gas emit less TtW GHG emissions than their peers, achieving $12.4-27 \%$ reductions compared to gasoline vehicles and $0-16.5 \%$ reduction versus their diesel counterpart. Thanks to the large fuel efficiency benefits, diesel powered vehicles achieve 9.3 - 13\% GHG emission reductions over gasoline and $0.5 \%$ to bi-fuel PISI natural gas vehicles. 


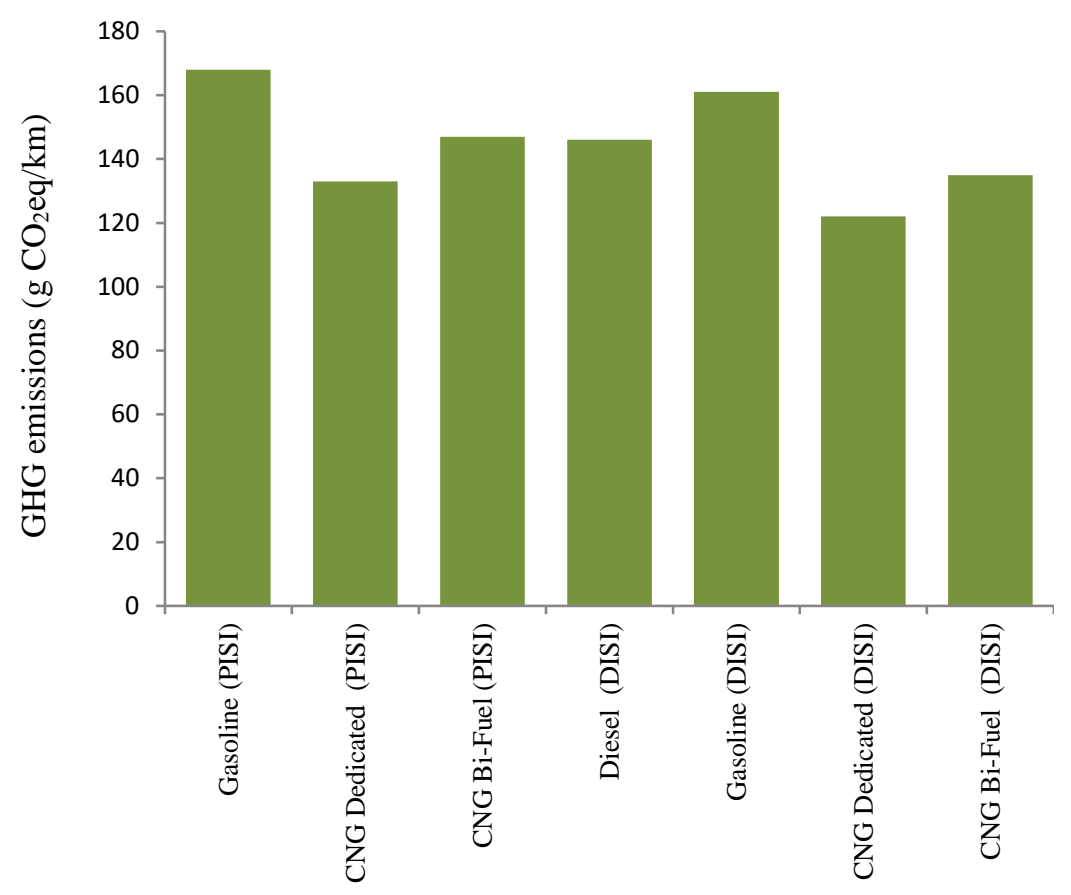

Fig. 7.TtW GHG emission for the selected powertrain technologies

The comparatively low GHG emission of natural gas fueled powertrain is primarily due to fact that the main constituent of $\mathrm{CNG}$ is methane $\left(\mathrm{CH}_{4}\right)$, the simplest alkane with only one carbon atom and consequently no carbon-to-carbon bonds. The simple chemical structure of methane makes it an inherently clean burning fuel than any other fossil fuel [42]. For instance, when combusted, natural gas releases 28 percent less carbon dioxide per unit of heat than diesel fuel [41].But on the other hand, methane is 28 times more potent greenhouse gas than carbon dioxide $\left(\mathrm{CO}_{2}\right)$ and its leakage from the engine can offset the emission benefits of CNG. Moreover being a major constituent of natural gas, the hydrocarbons emitted from a CNG engine are mainly composed of methane which is much harder to ignite in the after-treatment system then the heavier hydrocarbons associated with gasoline and diesel as it requires a much higher temperature of $540 \mathrm{C}^{\circ}$ when compared to gasoline $\left(258^{\circ} \mathrm{C}\right)$ or diesel $\left(316^{\circ} \mathrm{C}\right)$ [43]. For this reason, minimizing engine-out emissions of unburned methane is of great importance.

Methane is also emitted from gasoline and diesel vehicle but its quantity is much low ( 23\% at the level of NGVs [44] as compared to CNG vehicles. Methane is released in the engine due to incomplete or partial fuel combustion, which produces $\mathrm{CH}_{4}, \mathrm{CO}, \mathrm{PM}$ along with other unburned hydrocarbons. This usually occurs when the ratio of air to fuel in combustion chamber is too low for complete combustion i.e. there is inadequate oxygen to convert all $\mathrm{CH}_{4}$ present in the fuel to $\mathrm{CO}_{2}$ and $\mathrm{H}_{2} \mathrm{O}$ and heat. Based on theliterature review, crankcase and tailpipe emissions are the two largest sources of methane loss from natural gas vehicles and can be calculated by Eq. (1) [45]. 
Methane Loss (\%)

$$
=\left[\frac{\text { Mass } \mathrm{CH}_{4} \text { tailpipe }+ \text { Mass } \mathrm{CH}_{4} \text { crankcase }}{\text { Mass Fuel }}\right] \times 100
$$

Tailpipe methane emissions can be estimated from available literature. For example, Patrick E. et. al, 2014 [46] report CNG tailpipe emission factors of 0.015 grams of methane/ton-mile. Under the simplified assumption that natural gas composition is $100 \%$ methane (i.e., one mole of $\mathrm{CO}_{2}$ is produced per mole of fuel burned), $0.05 \%$ of the fuel is lost through the tailpipe. Similarly Carder et al. , 2014 [47] estimated tailpipe methane loss at $0.21 \%$ for stoichiometric natural gas engines. Dunn et al., 2013 [48] report that 15L HD HPDI natural gas engine dynamometer tests over the Supplemental Emissions Test (SET) cycle reveal tailpipe methane at 0.65 to 0.75 grams per kilowatt-hour (kWh), which translates to a $0.48 \%$ methane loss. In another study Frazier (2013) [49] registers methane levels at $1.7 \mathrm{~g} / \mathrm{bhp}-\mathrm{hr}$, which translates to a $0.92 \%$ tailpipe methane loss. We estimate the tailpipe methane emissions for natural gas vehicles in the range of $0.45-0.6 \%$ depending upon the engine and fuel injection type e.g. dedicated CNG engine, PISI, DISI.

Crankcase emissions, also known as "blow-by" emissions, are released directly from the engine into the atmosphere through a vent. Literature values for crankcase emissions are scarce. Researchers from West Virginia University's Center for Alternative Fuels, Engines, and Emissions (CAFEE) [50] recently conducted methane leak and loss audits of large-bore gas engines at five different gas compressor stations and the resulted crankcase emissions represent a loss of 0.1 to $0.6 \%$. US EPA 2014 GHG certification data [51] for natural gas engines show that combined (tailpipe and crankcase) methane emissions for stoichiometric natural gas engines range from 0.6 to $1.2 \%$ of the fuel (US EPA, 2014). Ebner and Jaschek 1998 [52] concluded that typical piston ring blow-by losses are in the range of $0.5-1 \%$. Keeping in view the engine technologies available in Pakistan we approximate the crankcase methane emissions at level of $0.8 \%$.Fig. 8 reports the share of methane (in gram of $\mathrm{CO}_{2}$ equivalent per $\mathrm{km}$ ) in total TtW GHG emission for natural gas fueled powertrains. In can be noted that in terms of global warming potential, the share of methane emission varies from $26 \%$ to $28 \%$ in TtW GHG emissions of NGVs. 


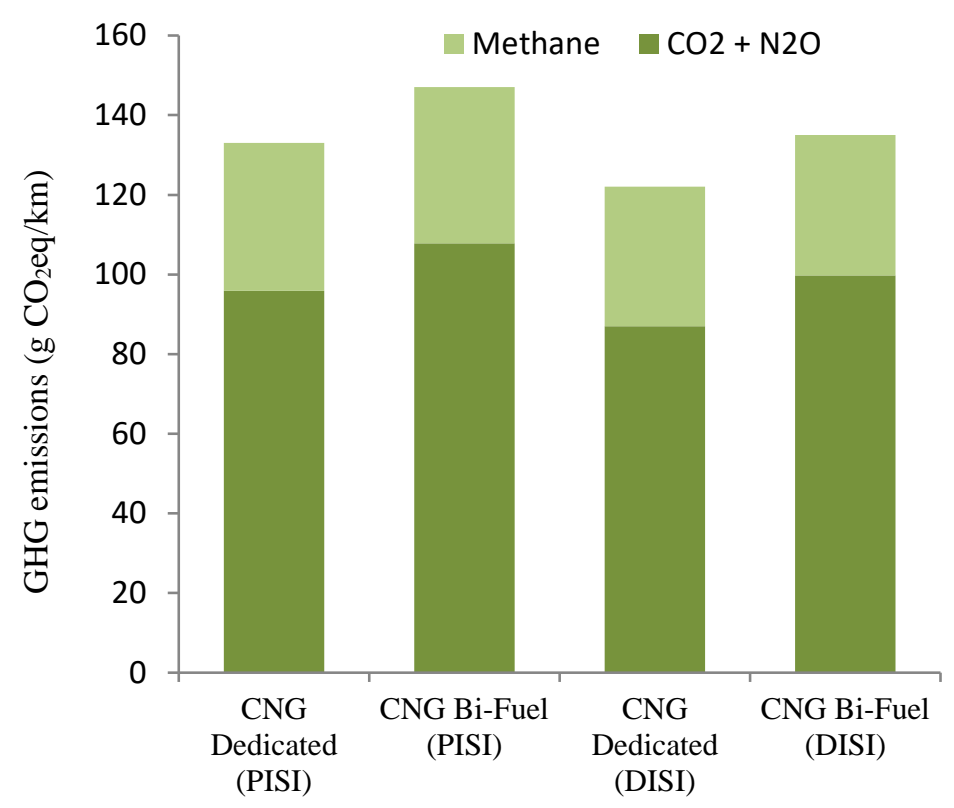

Fig. 8. Share of methane emission in TtW GHG emissions for natural gas fueled powertrains

\subsection{WtW Analysis}

As mentioned above the WtT cycle consist of two stages i.e (i) WtT stage, and (ii) TtW stage. The WtT stage of study has been covered in part-1 [33] of this two-part study. In this paper the Well-to-Tank (WtT) results observed in part-1[33] are combined with the TtW (Tank-to-Wheel) results reported in this present paper to provide the comprehensive WtW analysis of 25 combinations of automotive fuel and matching powertrain systems.

\subsection{WtW energy use}

The WtW energy use in MJ per kilometer of distance traveled is shown in Fig. 9. The analysis indicates that for all powertrains, a major contribution $(80-89 \%)$ of energy used in the overall WtW analysis comes from the TtW component. The diesel vehicles are the least energy consuming due to relatively lower energy use in the TtW phase as compared to gasoline and CNG vehicles. On the other hand, WtW energy consumption of NGVs are remained highest among all powertrains considered in this study. For NGVs the contribution of the TtW energy used is about $80 \%$ of the total WtW energy use. It is interesting to note that the indigenous natural gas has the lowest WtT energy consumption among all fuel pathways but in terms of WtW energy consumption it is above the diesel and gasoline vehicles. It is mainly due to low energy density of natural gas which conduces to $10-15 \%$ power loss during vehicle operation stage. The dedicated DISI natural gas vehicles resulted in $1.5 \%-12.5 \%$ and $3 \%-8.5 \%$ less energy consumption as compared to PISI gasoline and DISI gasoline vehicles, respectively. It is mainly because of $\sim 20 \%$ increase in the compression ratio (12.5) of dedicated DISI natural gas engine as compared to 10.5 compression ratio of conventional gasoline engine. Conventional dedicated PISI natural gas fueled vehicles are unable to compete with the conventional PISI gasoline WtW energy demand via imported LNG and interstate pipeline natural gas pathways due to a lower overall energy conversion efficiency chain. However, indigenous natural gas 
pathways for dedicated NGVs offer efficiency gains with the potential to bridge the gap between gasoline and NGVs WtW performance. In general dedicated CNG vehicles are currently slightly less efficient than equivalent gasoline vehicles while diesel vehicles enjoy a net advantage.

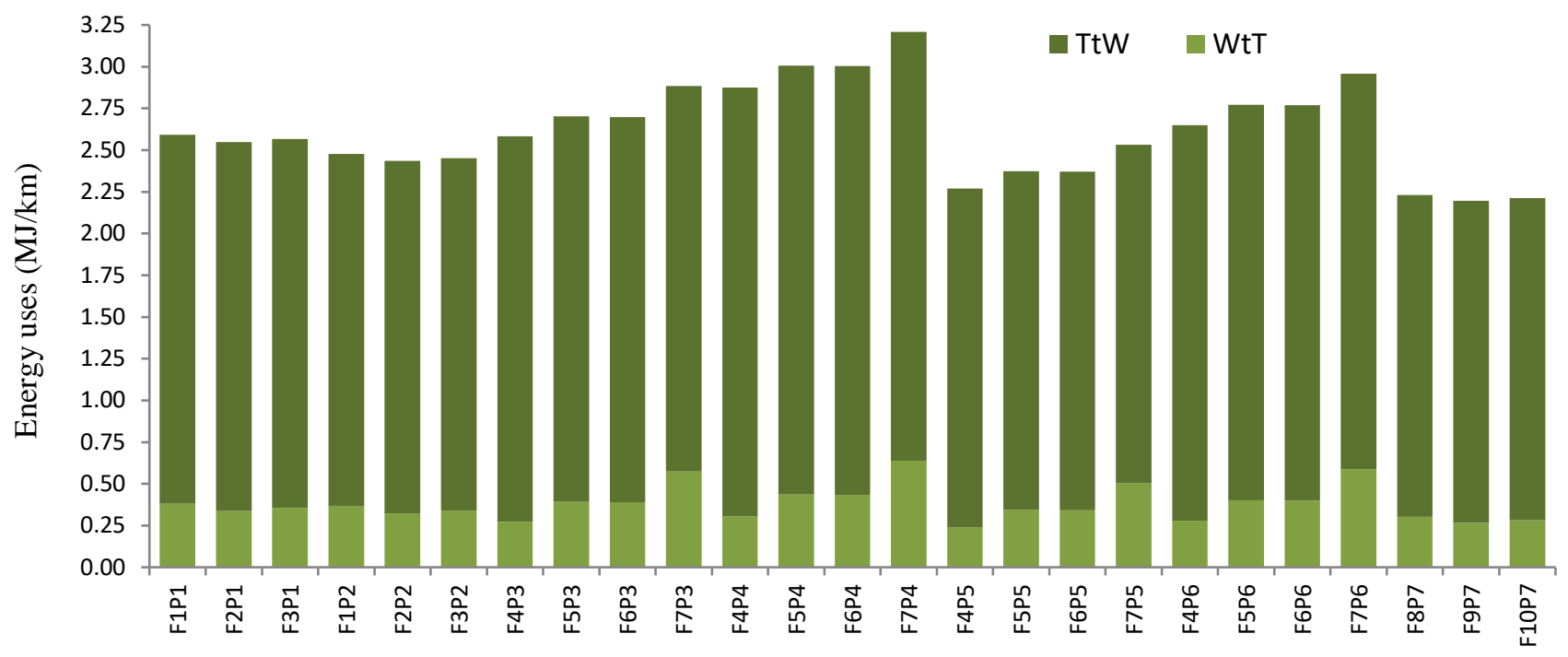

Fig.9. WtW energy uses for the selected powertrain technologies

\subsection{WtW GHG emissions}

The GHG emissions during different $\mathrm{WtW}$ stages of $\mathrm{CNG}$, gasoline and diesel powered light duty vehicles are shown in Fig. 10. For all powertrains, the majority of GHG emissions (73$86 \%$ ) are produced in the $\mathrm{TtW}$ stage. It can bee see that the gasoline vehicles are the most GHGemitting configuration followed by bi-fuel PISI natural gas vehicles and diesel vehicles. The dedicated CNG vehicles equipped with DISI engine technology show the lowest GHG emissions among all powertrains. To make the WtW GHG emission of natural gas powertrains on a par with their diesel equivalents, $\sim 11 \%$ reduction in WtW GHG emission would be needed which can be achieved by converting bi-fuel CNG vehicle to dedicated CNG vehicle. Though the energy consumption for dedicated CNG vehicles is higher as compared to diesel vehicles, the GHG emissions for $\mathrm{CNG}$ are comparable with those of diesel vehicles due to the less carbon content in CNG fuel which produces lower $\mathrm{CO}_{2}$ in the $\mathrm{TtW}$ stage. Also, it can be seen that the total WtW GHG emissions emitted by dedicated DISI CNG powered vehicles are roughly 8\% less than for the diesel powered vehicles. In general for natural gas powertrain, the higher relative $\mathrm{WtW}$ GHG emissions reductions in this study are mainly from the vehicle operation phase where recent advances in $\mathrm{CNG}$ engine technology are expected to improve the environmental value proposition of such vehicles. However, considering GHG emissions associated with the diesel powertrain as the baseline, operating conventional gasoline engine with CNG fuel offers limited advantage in terms of GHG emissions reductions. Overall the distributions of $\mathrm{WtW}$ GHG emissions from natural gas pathways are found to be wider than those from petroleum pathways. 


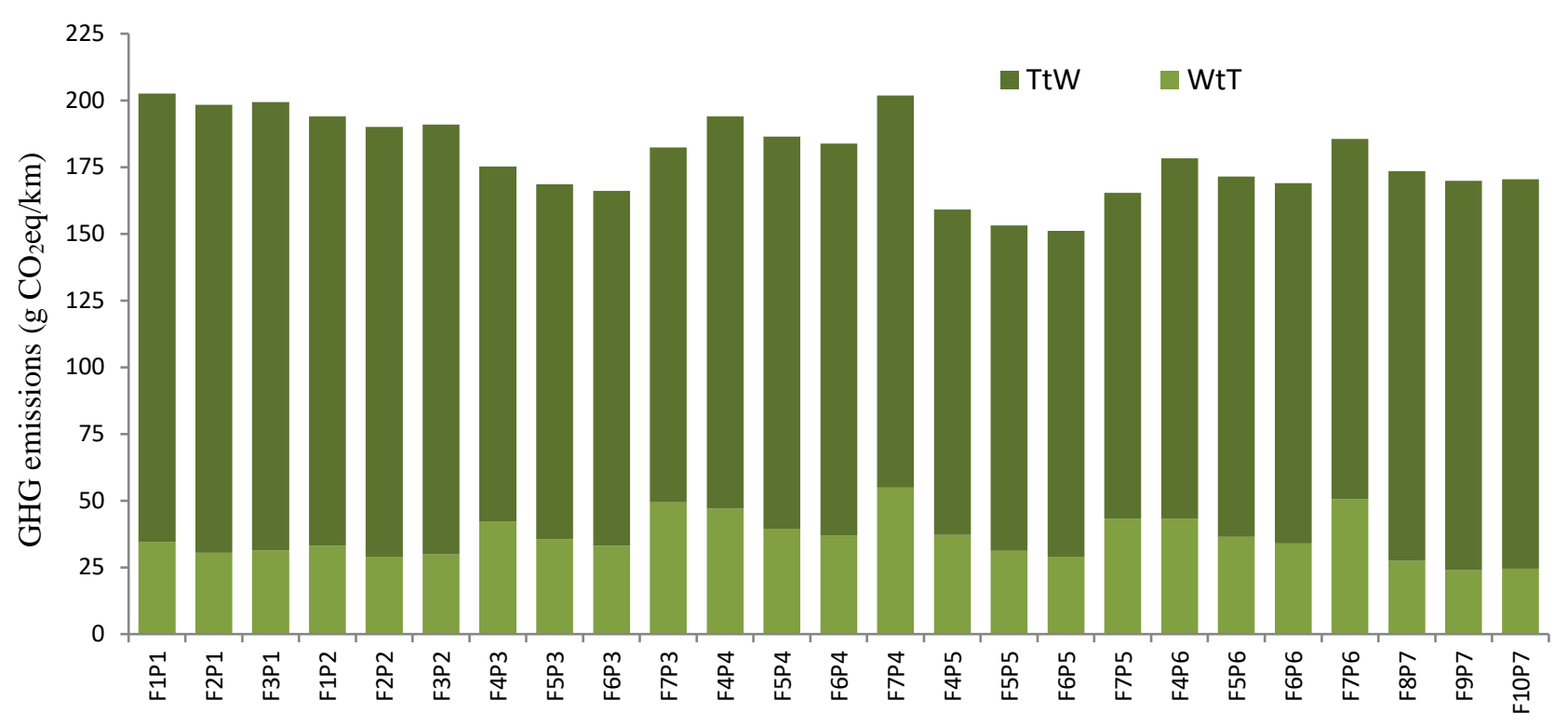

Fig.10. WtW GHG emissions for the selected powertrain technologies

\subsection{GWP time horizon and sensitivity analysis}

In this section, GHG emissions' estimates are conducted using global warming potentials (GWPs) of non- $\mathrm{CO}_{2}$ greenhouse gases with time frame of 20-years and compared the results with the with 100-year GWP (baseline scenario). A sensitivity analysis was then performed to explore the effect of variability on our estimates of WtW GHG emissions.

In the previous life-cycle studies [F. Orsi 2016; W, Ke, Waller, 2014, Edwards 2014, Ally 2007], there is a persistent use of the 100-year impact of methane on global warming, a factor about 28 times that of $\mathrm{CO}_{2}$. However, the current scientific consensus on climate change, summarized in IPCC AR 5 [32], says that we only have about 20-30 years before we reach the warning zone of temperature rise that could lead to climate tipping points. We can't wait 20-30 years to start decreasing CO2eq emissions from fossil fuels. Over a 20-year period, the consensus impact factor for methane is about 84.There is no scientific justification for the use of a 100-year period. The choice of GWP value could have serious impacts on the actual and relative results of this study. As methane is the major contributor to the life cycle GHG emission of natural gas so we will concentrate our discussion on the natural gas pathways only.

Estimates using both 100-year GWPs and 20-year GWPs are presented side by side for each powertrain technology in Fig. 11. It can be observed that the choice of GWP time horizon could have serious impacts on the WtW GHG emission results of this study. Using 20-year GWP, increases the WtW emissions of natural gas pathways from $179 \mathrm{~g} \mathrm{CO}_{2} \mathrm{eq} / \mathrm{km}$ to $253 \mathrm{~g} \mathrm{CO}_{2} \mathrm{eq} / \mathrm{km}$ (ranging between 64 and $77 \mathrm{~g} \mathrm{CO}_{2} \mathrm{eq} / \mathrm{MJ}$ ), an increase of about $19-26 \%$ from the baseline estimates of 100-year GWP. The obvious reason for this significant increase in the GHG emission is associated with a high risk of methane emission in natural gas fuel pathways mainly in the WtT stage. It is observed that by using 100-year GWP, the GHG emission results for natural gas pathways was comparable to the corresponding results of diesel fuel while superior to 
that of gasoline powertrains. But in case of 20-year GWP, natural gas pathways worst performance in terms of WtW GHG emissions.

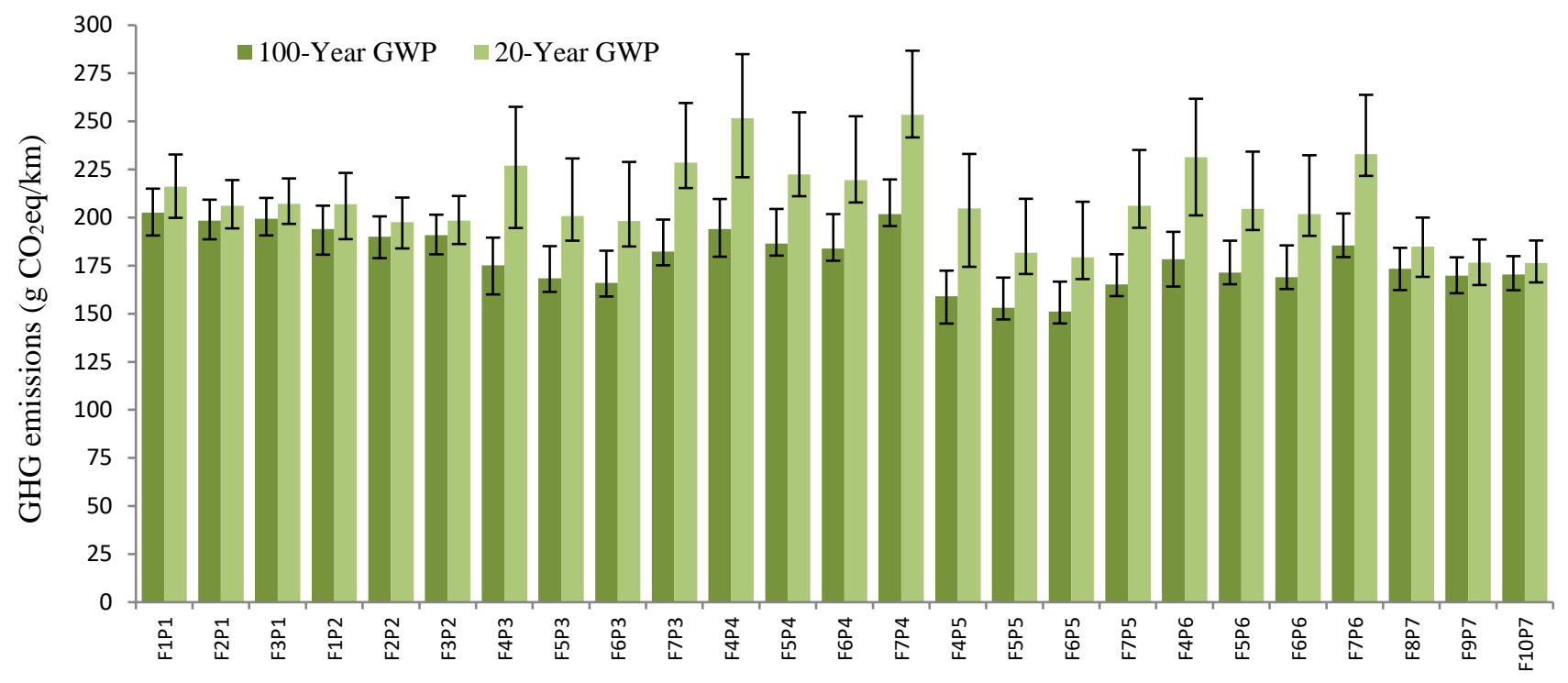

Fig.10. Uncertainty analysis of WtW GHG emissions for the selected pathways using 100-year and 20-year GWP baseline.

Considering the WtW results of this study, two factors largely determine whether the NGVs provide WtW GHG emission reductions as compared to their diesel and gasoline counterparts: NGVs relative fuel economy and methane emission leakage during the WtT and $\mathrm{TtW}$ stages. Using methane emission by $50 \%$ above the reference case, increase the WtW GHG emission by $8-10 \%$ across natural gas pathways. However, if 20-year GWPs and high methane emission (i.e. $50 \%$ above the reference case) assumptions are jointly considered, WtW GHG emissions increase between 37 - $47 \%$ across natural gas pathways.

The results of this study, as well as those in the literature [53,54], suggest that methane leakage rate of natural gas pathways is the most important factor influencing whether natural gas fuel pathways achieve net emission reductions. Given the importance of this factor, we derive the break-even methane leakage rate of natural gas vehicles relative to baseline gasoline and diesel fuel vehicles. The break-even rate is the methane leakage rate at which WtW GHG emissions from a natural gas pathway equals that of conventional gasoline or diesel. Considering diesel vehicle as baseline, our analysis indicate that natural gas vehicles offer GHG emissions reductions to its counterpart powertrains i.e. diesel and gasoline if the WtW methane leakage rate is lower than $2.9 \%$ (using the 100 -year GWP) or 1.1\% (using the 20-year GWP) and $1.8 \%$ (using the 20-year GWP), respectively. A shorter time horizon (such as 20 years), which considers a higher warming potential of methane, requires a lower break-even rate than a longer time horizon (such as 100 years). 


\section{Comparison with other studies}

The WtW energy use and GHG emissions results of various studies and the present study are represented in Fig. 12. Generally speaking, detailed comparisons cannot be made among the findings of WtW analysis of similar fuel due to different methods of modeling, types of input data used, system boundaries, engine parameters etc. Different methodologies and assumptions in different studies make scenario comparison difficult or impossible. Therefore comparison of absolute results from these studies and our study are less meaningful, mainly because of different locale specific data and baseline hypotheses. However, comparison of the relative change in the results among these studies should improve our understanding of the range of energy and emission benefits of advanced vehicle technologies and alternative transportation fuels. We only compared our results to studies that explicitly reported $\mathrm{CO}_{2}, \mathrm{CH}_{4}$ and $\mathrm{N}_{2} \mathrm{O}$ emissions, thereby allowing for the expression of all study results in terms of 100-y GWPs reported in the Fifth Assessment Report of the Intergovernmental Panel on Climate Change (IPCC AR5). The comparison clearly shows that the current study for India follows the general trend (regarding change in WtW energy use with change in fuel-powertrain) when compared with earlier studies for other countries. The comparison shows that our estimate of WtW GHG emissions associated with natural gas pathways are between the values reported for European and Chinese market. The WtW GHG emission values of NGVs of this study are $20 \%$ higher than the WtW values for similar type vehicle reported in WtW study conducted by Europe's Joint Research Centre (JRC) [21] in 2014. This is mainly due to high rate of fugitive GHG emission during pipeline transmission and distribution of natural gas in Pakistan as compared to that of Europe. Similarly for gasoline and diesel fuel, the comparison clearly shows that the current study for Pakistan follows the general trend regarding WtT GHG emission when compared with earlier studies for other countries. Similarly for gasoline and diesel fuel, the comparison clearly shows that the current study for Pakistan follows the general trend regarding WtW GHG emission and energy use when compared with earlier studies for other countries.
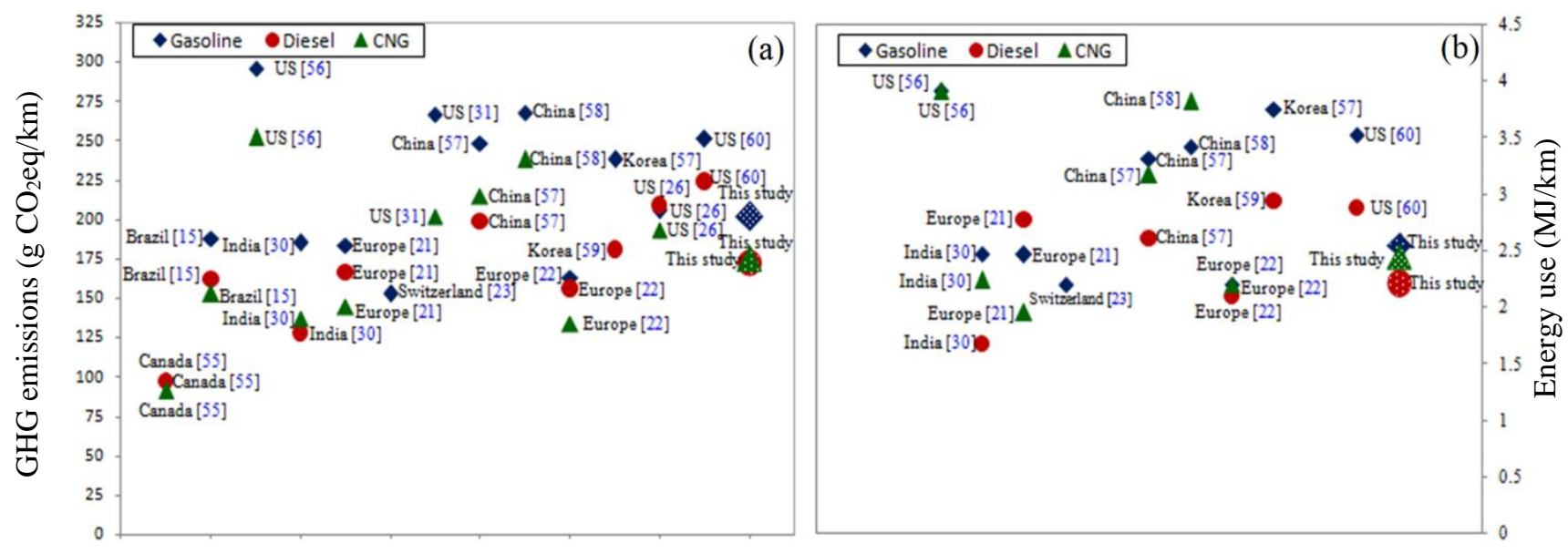

Fig. 12. Results comparison of the present study with those reported in the literature (a) WtW GHG emission (b) energy use 


\section{Conclusions}

The present study has been conducted to provide detailed WtW assessment of energy consumptions and GHG emissions of natural gas, gasoline and diesel fuel pathways at the Pakistan and energy importing developing countries levels. The results of the present study can be used as an input to the strategic decision-making process for future transport energy policy and also to identify key areas of interest for further technology research and development of the Pakistan transport system. Furthermore, it could also provide an important tool for policy makers to better understand trade-offs between energy and environmental effects for the most effective use of regional energy resources.

This study presents a comprehensive comparison of operational WtW analysis for 25 combinations of automotive fuel and matching powertrain systems. Key finding are listed below:

- In contrast, natural gas fueled vehicles are at a disadvantage from the standpoint of energy consumption e.g. on WtW basis, NGVs are $5-17 \%$ and $23-36 \%$ less fuel efficient, depending on the engine technology employed as compared to gasoline and diesel powertrain, respectively.

- Natural gas appears as an efficient pathway regarding GHG emissions, especially compared to gasoline. Dedicated NGV equipped with direct injection technology is even more efficient and may result in $20 \%$ and $12 \%$ less GHG emissions as compared to gasoline and diesel pathways, respectively. The environmental and energetic assessments of NGV appear to be very favorable to this technology (i.e. dedicated DISI) and make CNG a promising fuel for light duty road transport vehicles. However WtW GHG emissions of the prevalent bi-fuel NGVs are $12 \%$ higher than those of their diesel counterparts with the baseline estimates of 100-year GWP.

- In terms of WtW GHG emissions, natural gas pathways can attain better or comparable performance as compared to petroleum pathways, however retrofitted bi-fuel engine technology and Methane leakage during gas fuel production and vehicle operation stage, can negate the benefits of using NGVs. Thus without significant improvements in both methane leakage and engine efficiency, using natural gas in light-duty transport will not provide large GHG benefits. There are cost-effective technologies to reduce methane leakages in natural gas pathways. For instance natural gas engine with closed crankcase design that has reached the market can significantly reduce the TtW part of methane emission. Similarly the potential way to reduce the methane from WtT pathway, technologies are now available with help of which methane vented during gas production and processing can be captured and sequestered or used for energy at no net cost.

- A larger uncertainty and variability was observed in WtW GHG emissions of natural gas pathways as compared to conventional gasoline and diesel fuel. Moreover the choice of GWPs and methane emission estimates are other important factors for absolute emission levels and relative rankings of natural gas fuel pathways. Using 20-year GWPs instead of 100-year GWPs increases WtW GHG emissions by 19-26\% for natural gas pathways.

- While this paper focuses on GHG emissions, natural gas based fuels may provide other environmental benefits, such as the reduction of other air pollutants as well as significant economic advantage over petroleum based pathways but these issues are outside the scope of this work and will be addressed in future research.

- The results of this study serve as valuable inputs not only for policy decision-makers in Pakistan, but analysis would also be applicable to other countries having similar 
characteristics, i.e., oil importing developing countries with their own or easy access to natural gas resources (e.g., via relatively short distance pipelines); some countries in Latin America, Africa and Southeast Asia would seem to fit this description.

\section{Acknowledgements}

The authors are thankful to AVL List GmbH for providing licenses to AVL CRUISE under AST-University Partnership Program with University of Engineering \& Technology, Peshawar, Pakistan.

\section{Nomenclature:}

$\begin{array}{ll}\text { AFR } & \text { Air fuel ratio } \\ \text { ANL } & \text { Argonne national laboratory } \\ \text { ATT } & \text { After-treatment technologies } \\ \text { API } & \text { American petroleum institute } \\ \text { BEV } & \text { Battery electric vehicle } \\ \text { BTU } & \text { British thermal unit } \\ \text { CAPP } & \text { Canadian association of petroleum producers } \\ \text { CH4 } & \text { Methane } \\ \text { CI } & \text { Compression ignition } \\ \text { CN } & \text { Cetane number } \\ \text { CNG } & \text { Compressed natural gas } \\ \text { CO } 2 & \text { Carbon dioxide } \\ \text { CO } & \text { CO }{ }_{2} \text { equivalent } \\ \text { DISI } & \text { Direct injection spark ignition } \\ \text { DICI } & \text { Direct injection compression lignition } \\ \text { DPF } & \text { Diesel particulate filter } \\ \text { DOC } & \text { Diesel oxidation catalyst } \\ \text { FCEV } & \text { fuel cell electric vehicle } \\ \text { GHG } & \text { Greenhouse gas } \\ \text { Gram per-kilometer }\end{array}$


GREET Greenhouse emissions and energy use in transportation

GWP Global warming potential

H/C Hydro-Carbon ratio

HEV Hybrid electric vehicle

IC Internal combustion

ICE Internal combustion engine

IP Iran Pakistan

IPCC Intergovernmental panel on climate change

IVE International Vehicle Emissions

JRC Joint research center

$\mathrm{Km} \quad$ Kilometer

$\mathrm{kW} \quad$ Kilowatt

$\mathrm{kWh} \quad$ Kilowatt hour

LCA Life cycle analysis

LHV Latent heat of vaporization

Lit Liter

LNG Liquefied natural gas

LNT Lean NOx traps

MJ Megajoule

MMSCFD Million cubic feet per day

NDCs Nationally determined contributions

NEDC New European drive cycle

$\mathrm{Nm} \quad$ Newton meter

$\mathrm{N}_{2} \mathrm{O} \quad$ Nitrous oxide

NG Natural gas

NGVs Natural gas vehicles

PISI Port injection spark ignition 


$\begin{array}{ll}\text { RON } & \text { Reteach octane number } \\ \text { rpm } & \text { Revolutions per minute } \\ \text { SCFB } & \text { Standard cubic feet per barrel } \\ \text { SCR } & \text { Selective catalytic reduction } \\ \text { SI } & \text { Spark ignition } \\ \text { SNGPL } & \text { Sui northern gas pipelines limited } \\ \text { SSGCL } & \text { Sui southern gas company limited } \\ \text { STEP } & \text { Sustainable transport energy program } \\ \text { TAPI } & \text { Turkmenistan Afghanistan Pakistan India } \\ \text { TOE } & \text { Ton of oil equivalent } \\ \text { TtW } & \text { Tank-to-Wheel } \\ \text { TWC } & \text { Three-way catalyst } \\ \text { WtT } & \text { Well-to-Tank } \\ \text { WtW } & \text { Well-to-Wheel } \\ \text { U.S. } & \text { United States }\end{array}$

\section{References:}

1. Pakistan Energy Yearbook, 2017. Hydrocarbon Development Institute of Pakistan; June 2018: Islamabad. Pakistan

2. Ministry of Climate Change. Pakistan National GHG Inventory 2014-2015; Government of Pakistan: Islamabad, Pakistan, 2016; pp. 2-3.

3. Khan, M.I. and Yasmin, T., 2014. Development of natural gas as a vehicular fuel in Pakistan: issues and prospects. Journal of Natural Gas Science and Engineering, 17, pp.99-109.

4. Bossel, U., 2003, October. Well-to-wheel studies, heating values, and the energy conservation principle. Technical report, European Fuel Cell Forum, Morgenacherstrasse.

5. Di Lullo, G., Zhang, H. and Kumar, A., 2016. Evaluation of uncertainty in the well-to-tank and combustion greenhouse gas emissions of various transportation fuels. Applied energy, 184, pp.413-426.

6. Qiao, Q., Zhao, F., Liu, Z., Jiang, S. and Hao, H., 2017. Cradle-to-gate greenhouse gas emissions of battery electric and internal combustion engine vehicles in China. Applied Energy, 204, pp.1399-1411.

7. Bauer, C., Hofer, J., Althaus, H.J., Del Duce, A. and Simons, A., 2015. The environmental performance of current and future passenger vehicles: life cycle assessment based on a novel scenario analysis framework. Applied energy, 157, pp.871883.

8. Simons, A. and Bauer, C., 2015. A life-cycle perspective on automotive fuel cells. Applied Energy, 157, pp.884-896.

9. Wolfram, P. and Wiedmann, T., 2017. Electrifying Australian transport: Hybrid life cycle analysis of a transition to electric light-duty vehicles and renewable electricity. Applied Energy, 206, pp.531-540.

10. Alam, M.S., Hyde, B., Duffy, P. and McNabola, A., 2017. Assessment of pathways to reduce CO2 emissions from passenger car fleets: Case study in Ireland. Applied energy, 189, pp.283-300

11. Lee, D.Y., Elgowainy, A. and Dai, Q., 2018. Life cycle greenhouse gas emissions of hydrogen fuel production from chloralkali processes in the United States. Applied Energy, 217, pp.467-479.

12. Bongartz, D., Doré, L., Eichler, K., Grube, T., Heuser, B., Hombach, L.E., Robinius, M., Pischinger, S., Stolten, D., Walther, G. and Mitsos, A., 2018. Comparison of light-duty transportation fuels produced from renewable hydrogen and green carbon dioxide. Applied Energy, 231, pp.757-767. 
13. Ke, W., Zhang, S., He, X., Wu, Y. and Hao, J., 2017. Well-to-wheels energy consumption and emissions of electric vehicles: Mid-term implications from real-world features and air pollution control progress. Applied energy, 188, pp.367377.

14. Morganti, K., Al-Abdullah, M., Alzubail, A., Kalghatgi, G., Viollet, Y., Head, R., Khan, A. and Abdul-Manan, A., 2017. Synergistic engine-fuel technologies for light-duty vehicles: Fuel economy and Greenhouse Gas Emissions. Applied Energy, 208, pp.1538-1561.

15. Orsi, F., Muratori, M., Rocco, M., Colombo, E. and Rizzoni, G., 2016. A multi-dimensional well-to-wheels analysis of passenger vehicles in different regions: Primary energy consumption, CO2 emissions, and economic cost. Applied Energy, 169, pp.197-209.

16. Hofmann, J., Guan, D., Chalvatzis, K. and Huo, H., 2016. Assessment of electrical vehicles as a successful driver for reducing CO2 emissions in China. Applied energy, 184, pp.995-1003.

17. Yuan, X., Li, L., Gou, H. and Dong, T., 2015. Energy and environmental impact of battery electric vehicle range in China. Applied Energy, 157, pp.75-84.

18. Xu, Y., Gbologah, F.E., Lee, D.Y., Liu, H., Rodgers, M.O. and Guensler, R.L., 2015. Assessment of alternative fuel and powertrain transit bus options using real-world operations data: Life-cycle fuel and emissions modeling. Applied energy, 154, pp.143-159.

19. General Motors, Argonne National Laboratory, BP, ExxonMobil, and Shell. GM Well-to-wheel energy use and greenhouse gas emissions of advanced fuel/vehicle systems - North American analysis., General Motors Corporation and Argonne National Laboratory; USA, 2001.

20. Waller, M.G., Williams, E.D., Matteson, S.W. and Trabold, T.A., 2014. Current and theoretical maximum well-to-wheels exergy efficiency of options to power vehicles with natural gas. Applied Energy, 127, pp.55-63.

21. Edwards, R., Hass, H., Larive, J., Lonza, L., Mass, H. and Rickeard, D., 2014. Well-to-wheel analysis of future automotive fuels and powertrains in the European context. Well-to-wheels report version 4.a. 2014. Joint Research Centre, European Union.

22. Torchio, M.F. and Santarelli, M.G., 2010. Energy, environmental and economic comparison of different powertrain/fuel options using well-to-wheels assessment, energy and external costs-European market analysis. Energy, 35(10), pp.41564171.

23. Yazdanie, M., Noembrini, F., Dossetto, L. and Boulouchos, K., 2014. A comparative analysis of well-to-wheel primary energy demand and greenhouse gas emissions for the operation of alternative and conventional vehicles in Switzerland, considering various energy carrier production pathways. Journal of power sources, 249, pp.333-348.

24. Ally, J. and Pryor, T., 2007. Life-cycle assessment of diesel, natural gas and hydrogen fuel cell bus transportation systems. Journal of Power Sources, 170(2), pp.401-411.

25. Rose, L., Hussain, M., Ahmed, S., Malek, K., Costanzo, R. and Kjeang, E., 2013. A comparative life cycle assessment of diesel and compressed natural gas powered refuse collection vehicles in a Canadian city. Energy Policy, 52, pp.453-461.

26. Tong, F., Jaramillo, P. and Azevedo, I.M., 2015. Comparison of life cycle greenhouse gases from natural gas pathways for light-duty vehicles. Energy \& Fuels, 29(9), pp.6008-6018.

27. Tong, F., Jaramillo, P. and Azevedo, I.M., 2015. Comparison of life cycle greenhouse gases from natural gas pathways for medium and heavy-duty vehicles. Environmental science \& technology, 49(12), pp.7123-7133.

28. Karman, D., 2006, May. Life-cycle analysis of GHG emissions for CNG and diesel buses in Beijing. In EIC Climate Change Technology, 2006 IEEE (pp. 1-6). IEEE.

29. Ou, X., Zhang, X. and Chang, S., 2010. Alternative fuel buses currently in use in China: life-cycle fossil energy use, GHG emissions and policy recommendations. Energy Policy, 38(1), pp.406-418.

30. Patil, V., Shastry, V., Himabindu, M. and Ravikrishna, R.V., 2016. Life-cycle analysis of energy and greenhouse gas emissions of automotive fuels in India: Part 2-Well-to-wheels analysis. Energy, 96, pp.699-712.

31. Curran, S.J., Wagner, R.M., Graves, R.L., Keller, M. and Green Jr, J.B., 2014. Well-to-wheel analysis of direct and indirect use of natural gas in passenger vehicles. Energy, 75, pp.194-203.

32. Stocker, T. ed., 2014. Climate change 2013: the physical science basis: Working Group I contribution to the Fifth assessment report of the Intergovernmental Panel on Climate Change. Cambridge University Press.

33. Khan, M.I., 2018. Comparative Well-to-Tank energy use and greenhouse gas assessment of natural gas as a transportation fuel in Pakistan. Energy for Sustainable Development, 43, pp.38-59.

34. Dia, H., Panwai, S., Boongrapue, N., Ton, T., Smith, N., 2006. Comparative evaluation of power-based environmental emissions models. In: Proceedings of the IEEE Intelligent Transportation Systems Conference (ITSC06). Toronto, Canada, pp. 1251-1256.

35. Aguiléra, V. and Tordeux, A., 2014.A new kind of fundamental diagram with an application to road traffic emission modeling. Journal of Advanced Transportation, 48(2), pp.165-184.

36. AVL. AVL cruise - vehicle system and driveline analysis. 2018. https://www.avl.com/cruise 
37. Wahono, B., Santoso, W.B. and Nur, A., 2015. Analysis of range extender electric vehicle performance using vehicle simulator. Energy Procedia, 68, pp.409-418.

38. Sciarretta, A., Back, M. and Guzzella, L., 2004. Optimal control of parallel hybrid electric vehicles. IEEE Transactions on control systems technology, 12(3), pp.352-363.

39. Vock, C., Ntziachristos, L., 2014. Vehicle energy/emission simulator for conventional and advanced passenger cars.ICTEmissions Consortium.

40. Heywood, J.B., 2018. Internal combustion engine fundamentals. McGraw-Hill Education.

41. Khan, M.I., Yasmin, T. and Shakoor, A., 2015. Technical overview of compressed natural gas (CNG) as a transportation fuel. Renewable and Sustainable Energy Reviews, 51, pp.785-797.

42. Kakaee, A.H. and Paykani, A., 2013. Research and development of natural-gas fueled engines in Iran. Renewable and Sustainable Energy Reviews, 26, pp.805-821.

43. Fino, D., Solaro, S., Russo, N., Saracco, G. and Specchia, V., 2007. Catalytic removal of methane over thermal-proof nanostructured catalysts for CNG engines. Topics in Catalysis, 42(1-4), pp.449-454.

44. Nam, E.K., Jensen, T.E. and Wallington, T.J., 2004. Methane emissions from vehicles. Environmental science \& technology, 38(7), pp.2005-2010.

45. Johnson, D.R., Heltzel, R., Nix, A.C., Clark, N. and Darzi, M., 2017. Greenhouse gas emissions and fuel efficiency of in-use high horsepower diesel, dual fuel, and natural gas engines for unconventional well development. Applied Energy, 206, pp.739-750

46. Meyer, P.E., Green, E.H., Corbett, J.J., Mas, C. and Winebrake, J.J., 2011. Total fuel-cycle analysis of heavy-duty vehicles using biofuels and natural gas-based alternative fuels. Journal of the Air \& Waste Management Association, 61(3), pp.285294.

47. Carder, D. K., Gautam, M., Thiruvengadam, A., Besch, M. (2014). In-use emissions testing and demonstration of retrofit technology for control of on-road heavy-duty engines. Center for Alternative Fuels, Engines, and Emissions, West Virginia University.

48. Dunn, M.E., McTaggart-Cowan, G.P. and Saunders, J., 2013, November. High Efficiency and Low Emission Natural Gas Engines for Heavy Duty Vehicles. In IMechE Internal Combustion Engines Conference, London, UK.

49. Frazier, T. (2013). Cummins Westport natural gas fueled engines. Presented at the National Academy of Sciences committee meeting: Assessment of technologies for reducing the fuel consumption of medium- and heavy-duty vehicles, Phase 2. Sacramento, Calif. July 31-August 1.

50. Johnson, D. and Covington, A., 2014, October. Methane Leak and Loss Audits of Natural Gas Fueled Compressor. In ASME 2014 Internal Combustion Engine Division Fall Technical Conference (pp. V001T04A006-V001T04A006). American Society of Mechanical Engineers

51. U.S. Environmental Protection Agency (US EPA) (2014). On-highway heavy-duty - diesel and gasoline engine certification data. Retrieved from https://19january2017snapshot.epa.gov/compliance-and-fuel-economy-data/engine-certificationdata_html

52. Ebner, H.W. and Jaschek, A.O., 1998. The importance of blow-by measurements, measuring equipment required and implementation (No. 981081). SAE Technical Paper.

53. Alvarez, R.A., Pacala, S.W., Winebrake, J.J., Chameides, W.L. and Hamburg, S.P., 2012. Greater focus needed on methane leakage from natural gas infrastructure. Proceedings of the National Academy of Sciences.

54. Meier, P.J., Holloway, T., Luedke, M., Frost, E.A., Scotty, E., Williams, S.P. and Bickford, E., 2013. Does Natural Gas Make Sense for Freight? Environmental and Resource Implications of the "Pickens Plan" (No. CFIRE 04-22).

55. Rahman, M.M., Canter, C. and Kumar, A., 2015. Well-to-wheel life cycle assessment of transportation fuels derived from different North American conventional crudes. Applied Energy, 156, pp.159-173.

56. Gao, L., 2011. Well-to-Wheels Analysis of Energy Use and Greenhouse Gas Emissions for Alternative Fuels. International Journal of Applied Science and Technology, 1(6).

57. Shen, W., Han, W., Chock, D., Chai, Q. and Zhang, A., 2012. Well-to-wheels life-cycle analysis of alternative fuels and vehicle technologies in China. Energy Policy, 49, pp.296-307

58. Wu, R., Li, G., Zhang, Z., Ren, Y. and Han, W., 2007. Life cycle analysis and choice of natural gas-based automotive alternative fuels in Chongqing Municipality, China. Frontiers of Environmental Science \& Engineering in China, 1(3), pp.292-298.

59. Choi, W. and Song, H.H., 2014. Well-to-wheel analysis on greenhouse gas emission and energy use with natural gas in Korea. The International Journal of Life Cycle Assessment, 19(4), pp.850-860.

60. Bandivadekar A, Bodek K, Lynette C, Evans C, Groode T, Heywood J, et al. On the road in 2035: reducing transportations petroleum consumption and GHG emissions. Laboratory for Energy and the Environment, Report No. LFEE 2008- 05 RP. Massachusetts Institute of Technology; 2008. Retrieved from: https://mitei.mit.edu/system/files/OnpthepRoadpinp2035_MIT_Julyp2008.pdf. 
Appendix A. Statistics and sources of fuels used by Pakistan's road transport [1]

\begin{tabular}{|c|c|c|c|}
\hline Description & Million TOE & MJ & Remarks \\
\hline \multicolumn{4}{|l|}{ Energy consumption by road transport } \\
\hline Pakistan total energy consumption & 50.12 & $2.216 \times 10^{12}$ & \\
\hline Road transport share in total energy consumption & 16.51 & $7.297 \times 10^{11}$ & $\begin{array}{l}\text { Road transport sector consuming } 33.93 \% \text { of the country total } \\
\text { energy requirement. }\end{array}$ \\
\hline Diesel share in road transport energy consumption & 7.83 & $2.914 \times 10^{11}$ & $\begin{array}{l}\text { Diesel fuel share } 47.46 \% \text { of total energy consumption by road } \\
\text { transport. }\end{array}$ \\
\hline $\begin{array}{l}\text { Gasoline share in road transport energy } \\
\text { consumption }\end{array}$ & 7.09 & $3.138 \times 10^{11}$ & $\begin{array}{l}\text { Gasoline fuel share } 43 \% \text { of total energy consumption by road } \\
\text { transport. }\end{array}$ \\
\hline CNG share in road transport energy consumption & 1.57 & $6.956 \times 10^{10}$ & $\begin{array}{l}\text { CNG fuel share } 9.53 \% \text { of total energy consumption by road } \\
\text { transport. }\end{array}$ \\
\hline \multicolumn{4}{|l|}{ Crude oil based fuels } \\
\hline Total crude oil processed by local refineries & 12.78 & $5.649 \times 10^{11}$ & $\begin{array}{l}\text { There are } 7 \text { refineries operating in Pakistan having total crude } \\
\text { processing capacity of } 19.37 \text { Million Tons per year. }\end{array}$ \\
\hline Indigenous Crude oil Production & 4.33 & $1.914 \times 10^{11}$ & $\begin{array}{l}\text { Currently Pakistan local crude oil production is } 100000 \text { barrels } \\
\text { per day. }\end{array}$ \\
\hline Foreign crude oil processed by local refineries & 8.95 & $3.958 \times 10^{11}$ & $\begin{array}{l}27 \% \text { crude oil need of local refineries is achieved through } \\
\text { foreign crude oil mostly from Saudi Arabia. }\end{array}$ \\
\hline Diesel production by local refineries & 4.81 & $2.129 \times 10^{11}$ & Sulfur content of local diesel is above $500 \mathrm{ppm}$. \\
\hline Diesel imports from foreign refineries & 3.99 & $1.764 \times 10^{11}$ & Foreign Crude oil is mostly imported from Saudi Arabia. \\
\hline Gasoline production by local refineries & 1.98 & $8.754 \times 10^{10}$ & RON of local gasoline is 90 . \\
\hline Gasoline imports from foreign refineries & 4.89 & $1.161 \times 10^{11}$ & Foreign Crude oil is mostly imported from Saudi Arabia. \\
\hline \multicolumn{4}{|l|}{ Natural gas based fuels } \\
\hline Total Ingenious Natural Gas Production & 30.18 & $1.335 \times 10^{12}$ & \\
\hline LNG Import & 4.46 & $1.970 \times 10^{11}$ & Since 2014 LNG is being imported mainly from Qatar. \\
\hline Planned natural gas import through TAPI pipeline & & & $\begin{array}{l}\text { The } 56 \text { inch, } 1600 \mathrm{~km} \text { gas pipeline project would supply } 1325 \\
\text { MMSCFD gas to Pakistan from Turkmenistan by the end of } \\
2019 \text {. }\end{array}$ \\
\hline Planned natural gas import through IP pipeline & & & $\begin{array}{l}\text { The } 42 \text { inch, } 1931 \mathrm{~km} \text { gas pipeline project would supply } 750 \\
\text { MMSCFD gas to Pakistan from Iran by the end of } 2018 \text {. }\end{array}$ \\
\hline Total Natural gas consumption & 29.30 & $1.295 \times 10^{12}$ & \\
\hline CNG Consumption & 1.57 & $6.956 \times 10^{10}$ & \\
\hline LNG share in total CNG consumption & 0.38 & $1.658 \times 10^{10}$ & \\
\hline $\begin{array}{l}\text { Total length of Pakistan natural gas transmission } \\
\text { Lines }\end{array}$ & $10789(\mathrm{~km})$ & & \\
\hline $\begin{array}{l}\text { Total length of Pakistan natural gas Distribution } \\
\text { Lines }\end{array}$ & $112474(\mathrm{~km})$ & & \\
\hline
\end{tabular}

